Prepared for the U.S. Department of Energy under Contract DE-AC05-76RL01830

\title{
Assessment of Energy Removal Impacts on Physical Systems: Hydrodynamic Model Domain Expansion, Refinement, and Online Dissemination of Model Results
}

\section{Environmental Effects of} Marine and Hydrokinetic Energy - Fiscal Year 2010

Z Yang

T Khangaonkar

T Wang

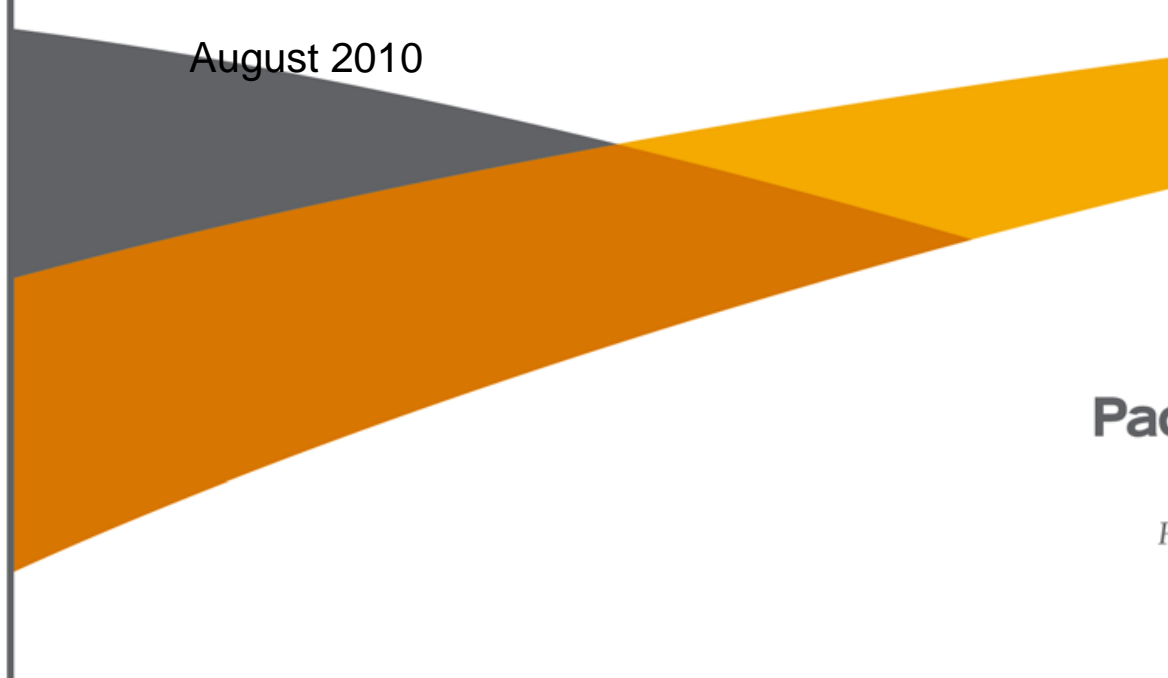




\title{
DISCLAIMER
}

This report was prepared as an account of work sponsored by an agency of the United States Government. Neither the United States Government nor any agency thereof, nor Battelle Memorial Institute, nor any of their employees, makes any warranty, express or implied, or assumes any legal liability or responsibility for the accuracy, completeness, or usefulness of any information, apparatus, product, or process disclosed, or represents that its use would not infringe privately owned rights. Reference herein to any specific commercial product, process, or service by trade name, trademark, manufacturer, or otherwise does not necessarily constitute or imply its endorsement, recommendation, or favoring by the United States Government or any agency thereof, or Battelle Memorial Institute. The views and opinions of authors expressed herein do not necessarily state or reflect those of the United States Government or any agency thereof.

\author{
PACIFIC NORTHWEST NATIONAL LABORATORY \\ operated by \\ BATTELLE \\ for the \\ UNITED STATES DEPARTMENT OF ENERGY \\ under Contract DE-AC05-76RL01830 \\ Printed in the United States of America \\ Available to DOE and DOE contractors from the \\ Office of Scientific and Technical Information, \\ P.O. Box 62, Oak Ridge, TN 37831-0062; \\ ph: (865) 576-8401 \\ fax: (865) 576-5728 \\ email: reports@adonis.osti.gov \\ Available to the public from the National Technical Information Service,
U.S. Department of Commerce, 5285 Port Royal Rd., Springfield, VA 22161
ph: (800) 553-6847
fax: (703) 605-6900
email: orders@ntis.fedworld.gov
online ordering: http://www.ntis.gov/ordering.htm
}

This document was printed on recycled paper. 


\title{
Assessment of Energy Removal Impacts on Physical Systems: Hydrodynamic Model Domain Expansion, Refinement, and Online Dissemination of Model Results
}

Environmental Effects of

Marine and Hydrokinetic Energy -

Fiscal Year 2010

\author{
Z Yang \\ T Khangaonkar \\ T Wang
}

August 2010

Prepared for

the U.S. Department of Energy

under Contract DE-AC05-76RL01830

Pacific Northwest National Laboratory

Richland, Washington 99352 



\begin{abstract}
In this report we describe 1) the expansion of the PNNL hydrodynamic model domain to include the continental shelf along the coasts of Washington, Oregon, and Vancouver Island and model refinement in neashore regions; and 2) the approach and progress in developing the online/Internet disseminations of model results and outreach efforts in support of the Puget Sound Operational Forecast System (PS-OPF). Submittal of this report completes the work on Task 2.1.2, Effects of Physical Systems, Subtask 2.1.2.1, Hydrodynamics, for fiscal year 2010 of the Environmental Effects of Marine and Hydrokinetic Energy project.
\end{abstract}





\section{Project Overview}

Energy generated from the world's oceans and rivers offers the potential to make substantial contributions to the domestic and global renewable energy supply. The U.S. Department of Energy (DOE) Office of Energy Efficiency and Renewable Energy (EERE) Wind and Water Power Program supports the emerging marine and hydrokinetic (MHK) energy industry. As an emerging industry, MHK project developers face challenges with siting, permitting, construction, and operation of pilot- and commercial-scale facilities, as well as the need to develop robust technologies, secure financing, and gain public acceptance.

In many cases, little is known about the potential effects of MHK energy generation on the aquatic environment from a small number of devices or a large-scale commercial array. Nor do we understand potential effects that may occur after years or decades of operation. This lack of knowledge affects the solvency of the industry, the actions of regulatory agencies, the opinions and concerns of stakeholder groups, and the commitment of energy project developers and investors.

To unravel and address the complexity of environmental issues associated with MHK energy, Pacific Northwest National Laboratory (PNNL) is developing a program of research and development that draws on the knowledge of the industry, regulators, and stakeholders and builds on investments made by the EERE Wind and Water Power Program. The PNNL program of research and development-together with complementary efforts of other national laboratories, national marine renewable energy centers, universities, and industry — supports DOE's market acceleration activities through focused research and development on environmental effects and siting issues. Research areas addressed include

- categorizing and evaluating effects of stressors - Information on the environmental risks from MHK devices, including data obtained from in situ testing and laboratory experiments (see other tasks below) will be compiled in a knowledge management system known as Tethys to facilitate the creation, annotation, and exchange of information on environmental effects of MHK technologies. Tethys will support the Environmental Risk Evaluation System (ERES) that can be used by developers, regulators, and other stakeholders to assess relative risks associated with MHK technologies, site characteristics, waterbody characteristics, and receptors (i.e., habitat, marine mammals, and fish). Development of Tethys and the ERES will require focused input from various stakeholders to ensure accuracy and alignment with other needs.

- effects on physical systems - Computational numerical modeling will be used to understand the effects of energy removal on water bodies from the short- and long-term operation of MHK devices and arrays. Initially, PNNL's three-dimensional coastal circulation and transport model of Puget Sound will be adapted to test and optimize simulated tidal technologies that resemble those currently in proposal, laboratory trial, or pilot study test stages. This task includes assessing changes to the physical environment (currents, waves, sediments, and water quality) and the potential effects of these changes on the aquatic food webs) resulting from operation of MHK devices at both pilot- and commercial-scale in river and ocean settings.

- effects on aquatic organisms - Testing protocols and laboratory exposure experiments will be developed and implemented to evaluate the potential for adverse effects from operation of MHK devices in the aquatic environment. Initial studies will focus on electromagnetic field effects, noise associated with construction and operation of MHK devices, and assessment of the potential risk of 
physical interaction of aquatic organisms with devices. A variety of fish species and invertebrates will be used as test animals, chosen due to their proximity to and potential susceptibility to MHK devices.

- permitting and planning - Structured stakeholder communication and outreach activities will provide critical information to the project team to support execution of other project tasks. Input from MHK technology and project developers, regulators and natural resource management agencies, environmental groups, and other stakeholder groups will be used to develop the user interface of Tethys, populate the database, define the risk attributes of the ERES, and communicate results of numerical modeling and laboratory studies of exposure of test animals to MHK stressors. This task will also include activities to promote consideration of renewable ocean energy in national and local Coastal and Marine Spatial Planning activities.

The team for the Environmental Effects of MHK Energy development project is made up of staff, faculty, and students from

- Pacific Northwest National Laboratory

o Marine Sciences Laboratory (Sequim and Seattle, Washington)

o Risk and Decision Sciences (Richland, Washington)

o Knowledge Systems (Richland, Washington)

- Oak Ridge National Laboratory (Oak Ridge, Tennessee)

- Sandia National Laboratories (Albuquerque, New Mexico; Carlsbad, California)

- Oregon State University, Northwest National Marine Renewable Energy Center (Newport, Oregon)

- University of Washington, Northwest National Marine Renewable Energy Center (Seattle, Washington)

- Pacific Energy Ventures (Portland, Oregon). 


\section{Acronyms and Abbreviations}

$\begin{array}{ll}\text { ADCIRC } & \text { Advanced Circulation (model) } \\ \text { DOE } & \text { U.S. Department of Energy } \\ \text { EERE } & \text { DOE Office of Energy Efficiency and Renewable Energy } \\ \text { ERES } & \text { Environmental Risk Evaluation System } \\ \text { FVCOM } & \text { Finite Volume Coastal Ocean Model } \\ \text { MHK } & \text { marine and hydrokinetic } \\ \text { NAM-WRF } & \text { North American Mesoscale - Weather Research and Forecasting (model) } \\ \text { NCEP } & \text { National Centers for Environmental Protection } \\ \text { NCOM } & \text { Navy Coastal Ocean Model } \\ \text { NOAA } & \text { National Oceanic and Atmospheric Administration } \\ \text { NOS } & \text { National Ocean Service } \\ \text { NRL } & \text { Naval Research Laboratory } \\ \text { NWS } & \text { National Weather Service } \\ \text { PS-CTM } & \text { Puget Sound Circulation and Transport Model } \\ \text { PNNL } & \text { Pacific Northwest National Laboratory } \\ \text { PS-OFS } & \text { Puget Sound Operational Forecast System } \\ \text { USGS } & \text { U.S. Geological Survey }\end{array}$





\section{Contents}

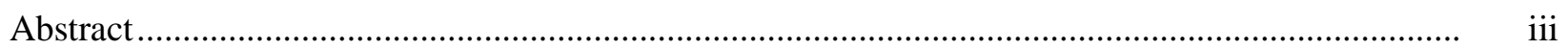

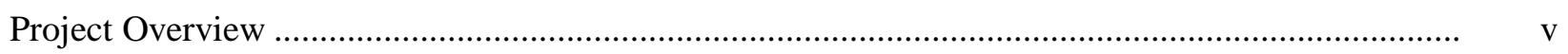

Acronyms and Abbreviations .......................................................................................................... vii

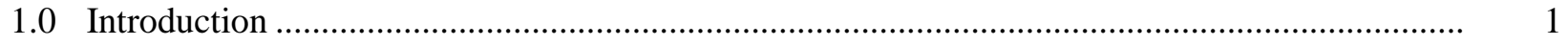

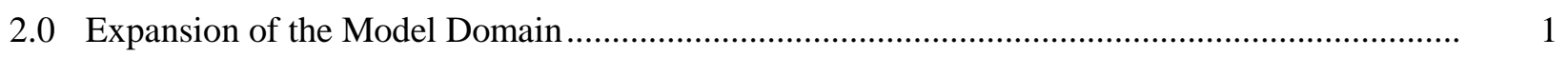

3.0 Online/Internet Dissemination of Model Results and Outreach............................................... 1

Appendix A - Conference Proceedings Paper ................................................................................. A.1

Appendix B - Submitted Journal Article........................................................................... B. B.

\section{Figures}

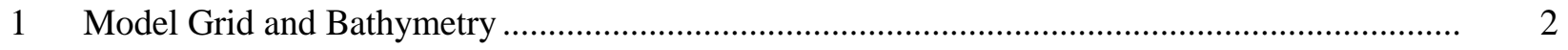

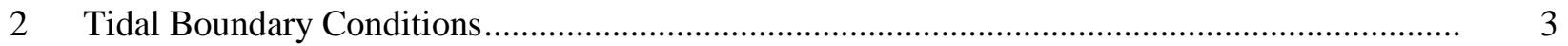

3 Predicted Tidal Elevations in Puget Sound............................................................................

4 Tidal Elevations at Low Tide and High Tide with Respect to South Sound ............................. 4

5 Tidal Currents at Ebb Tide and Flood Tide ........................................................................... 4

6 Architecture of the Puget Sound Operational Forecast System ................................................ 5 



\subsection{Introduction}

The task described in this report included two components: 1) expansion of the Puget Sound Operational Forecast System (PS-OPF) model domain to include the continental shelf along the coasts of Washington, Oregon, and Vancouver Island and 2) online/Internet disseminations of model results and outreach efforts, including continued development of the PS-OPF. The modeling effort and results of the dissemination subtask are summarized in the following sections.

\subsection{Expansion of the Model Domain}

To consider the effects of tidal energy propagating from the open ocean and upwelling, the existing Puget Sound model developed based on the Finite Volume Coastal Ocean Model (FVCOM) needed to be extended further out to the continental shelf. The hydrodynamic model of the Salish Sea was expanded to the continental shelf with inclusion of the coasts of Vancouver Island, Washington and Oregon. A new model grid with coverage of the northeastern Pacific Ocean was constructed using the University of Washington digital elevation model data as well as bathymetry data obtained from the National Oceanic and Atmospheric Administration (NOAA) (Figure 1). The model is driven by eight major tidal harmonics extracted from the Advanced Circulation (ADCIRC) model tide predictions in the Pacific Ocean.

The modeling effort also included refinement of nearshore regions and improvement of temperature simulation. Key regions such as Bellingham Bay and the Nisqually Estuary have been further refined in the updated model to better simulate the nearshore process in those important estuaries and bays.

Examples of tidal elevations at the southern and northern open boundaries are shown in Figure 2. Model runs were conducted to simulate tidal propagation along the Pacific Northwest coast and in Puget Sound. Time series plots of tidal elevations at the entrances to the Strait of Juan de Fuca, Admiralty Inlet, and Seattle harbor are shown in Figure 3. Water surface contours at high tide (with respect to Seattle) and low tide are presented in Figure 4. Velocity contours/vectors at flood tide and ebb tide are shown in Figure 5.

\subsection{Online/Internet Dissemination of Model Results and Outreach}

This component was completed and model results were presented to the 11th International Conference of Estuarine and Coastal Modeling (ECM11) in November 2009 in Seattle, Washington. The model now contains new components such as a linkage of hydrodynamic solution files to NOAA's oil spill trajectory model GNOME and real-time model validation to NOAA's Physical Oceanographic RealTime System (PORTS) datasets. A peer-reviewed paper was accepted for publication in the conference proceedings. ${ }^{1}$ A copy of the paper is provided in Appendix A. This subtask also included continued development of the PS-OFS, such as using NOAA Nation Centers for Environmental Protection (NCEP)

\footnotetext{
${ }^{1}$ Yang Z, T Khangaonkar, J Chase, and T Wang. Puget Sound Operational Forecast System - A Real-time Predictive Tool for Marine Resource Management and Emergency Responses. Tobe published by the American Society of Civil Engineers in the proceedings for the 11th International Conference on Estuarine and Coastal Modeling.
} 
meteorological outputs to drive sea temperate simulation in PS-OFS. A peer-reviewed manuscript describing this work was submitted for publication in the International Journal of Ocean and Climate Systems. ${ }^{2}$ Appendix B provides a copy of the manuscript submitted for review. The architecture of the PS-OFS is shown in Figure 6.

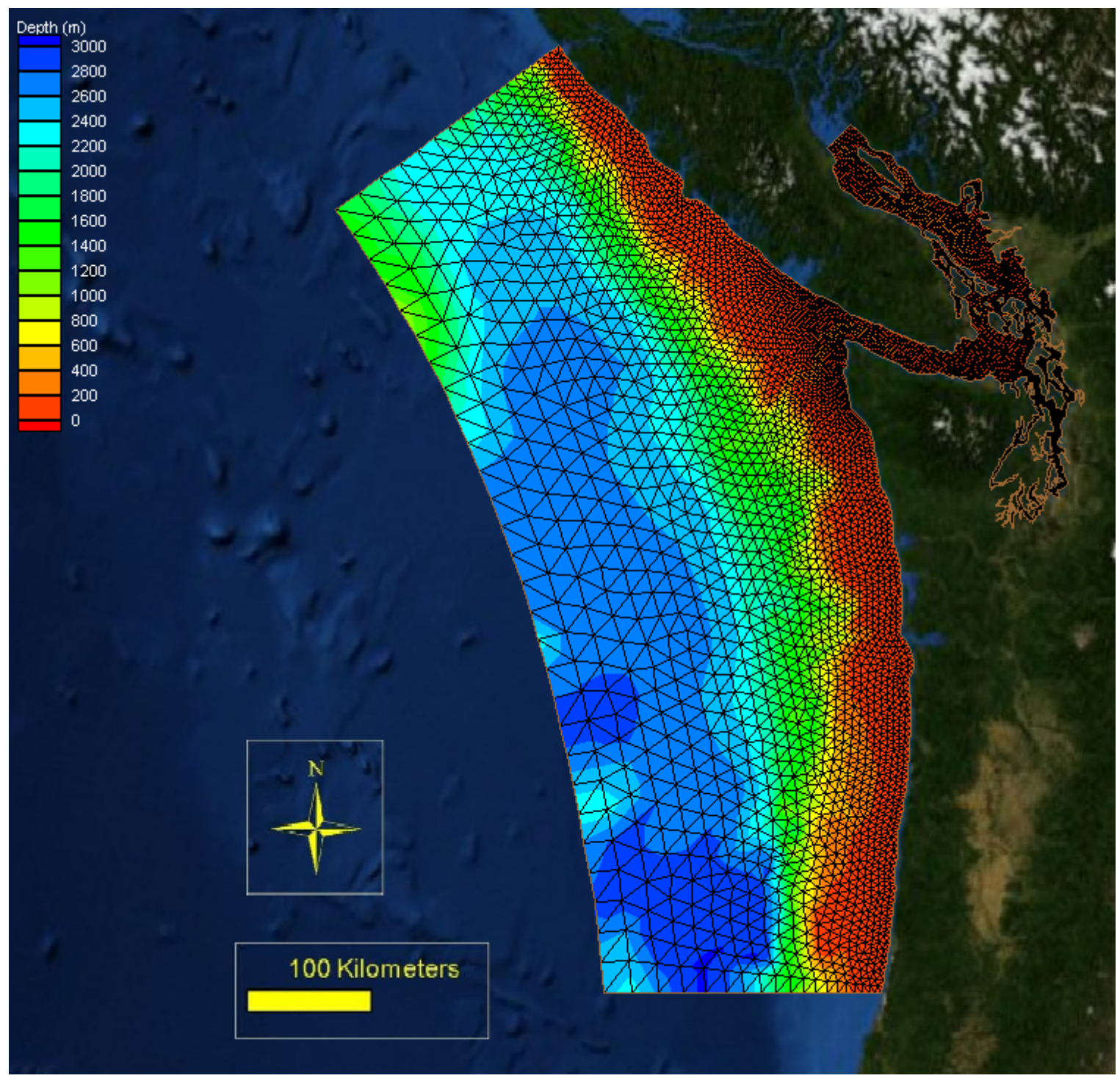

Figure 1. Model Grid and Bathymetry

\footnotetext{
${ }^{2}$ Yang Z, T Khangaonkar, and T Wang. Use of advanced meteorological model output for coastal ocean modeling in Puget Sound. International Journal of Ocean and Climate Systems; in review.
} 


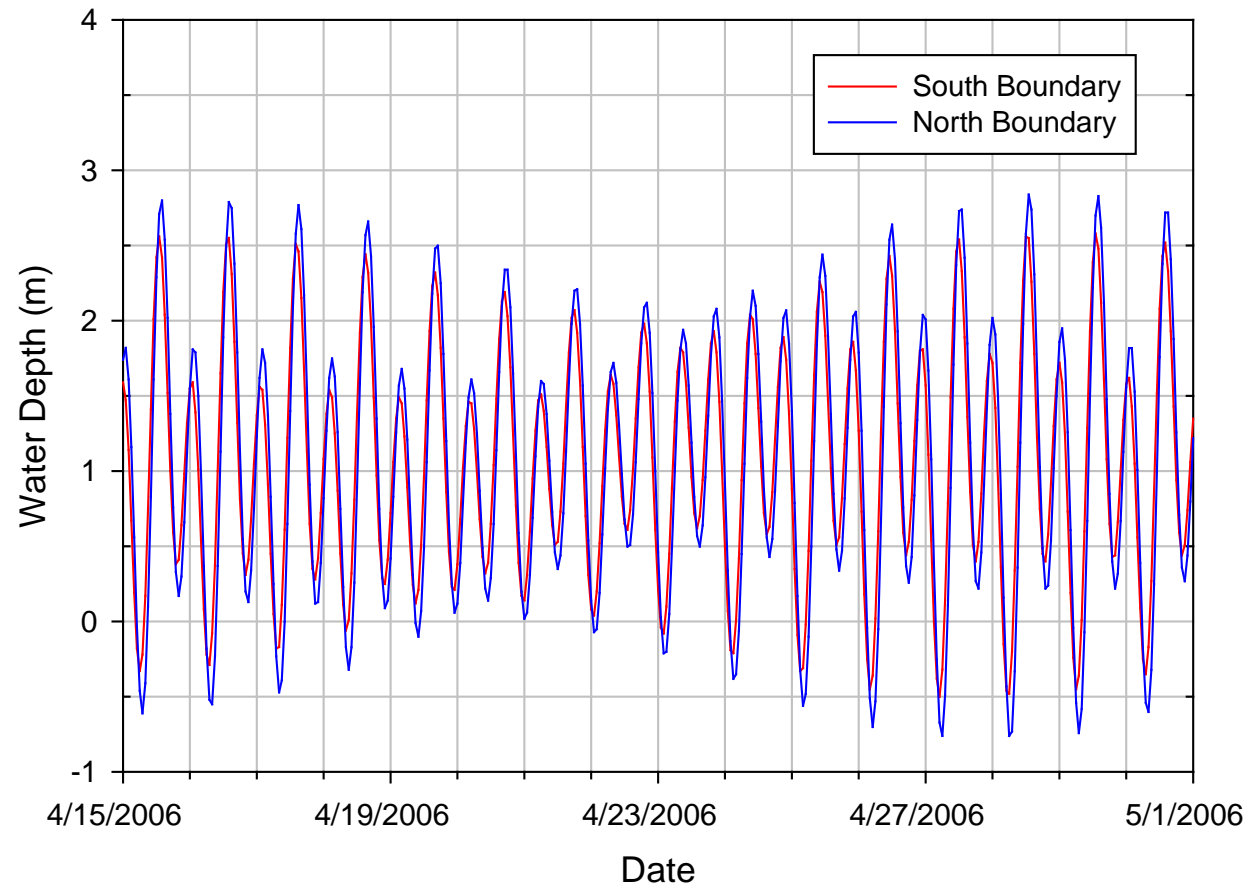

Figure 2. Tidal Boundary Conditions

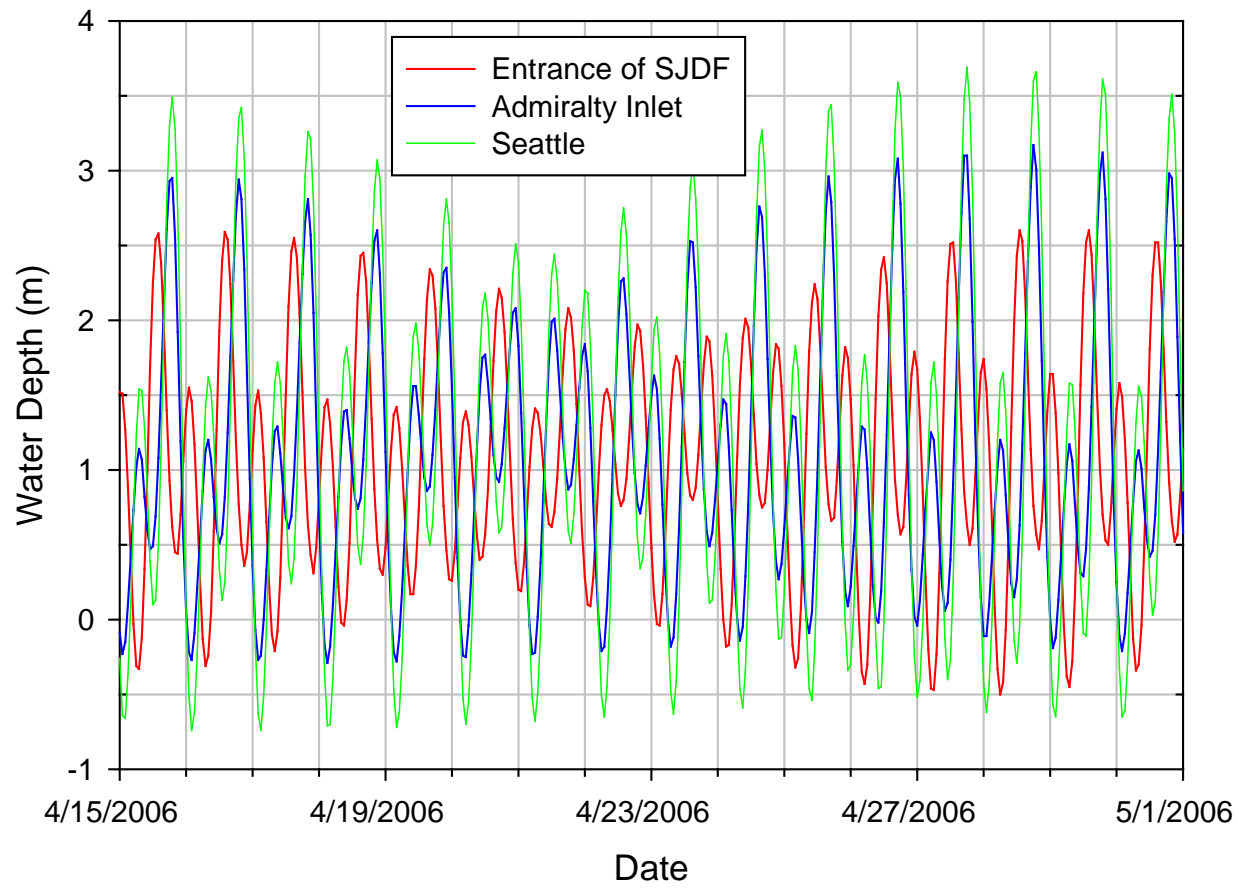

Figure 3. Predicted Tidal Elevations in Puget Sound 

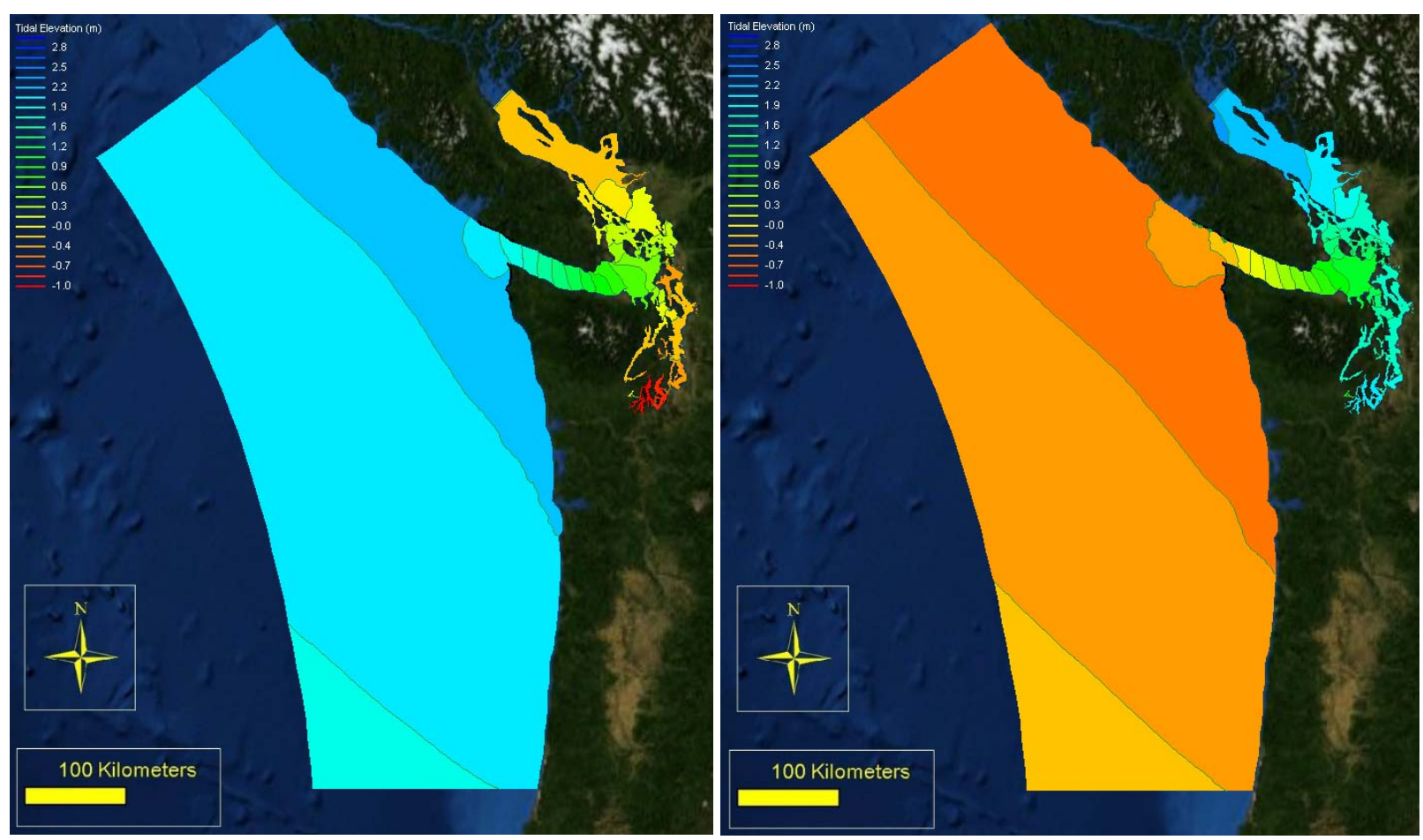

Figure 4. Tidal Elevations at Low Tide (Left Panel) and High Tide (Right Panel) with Respect to South Sound
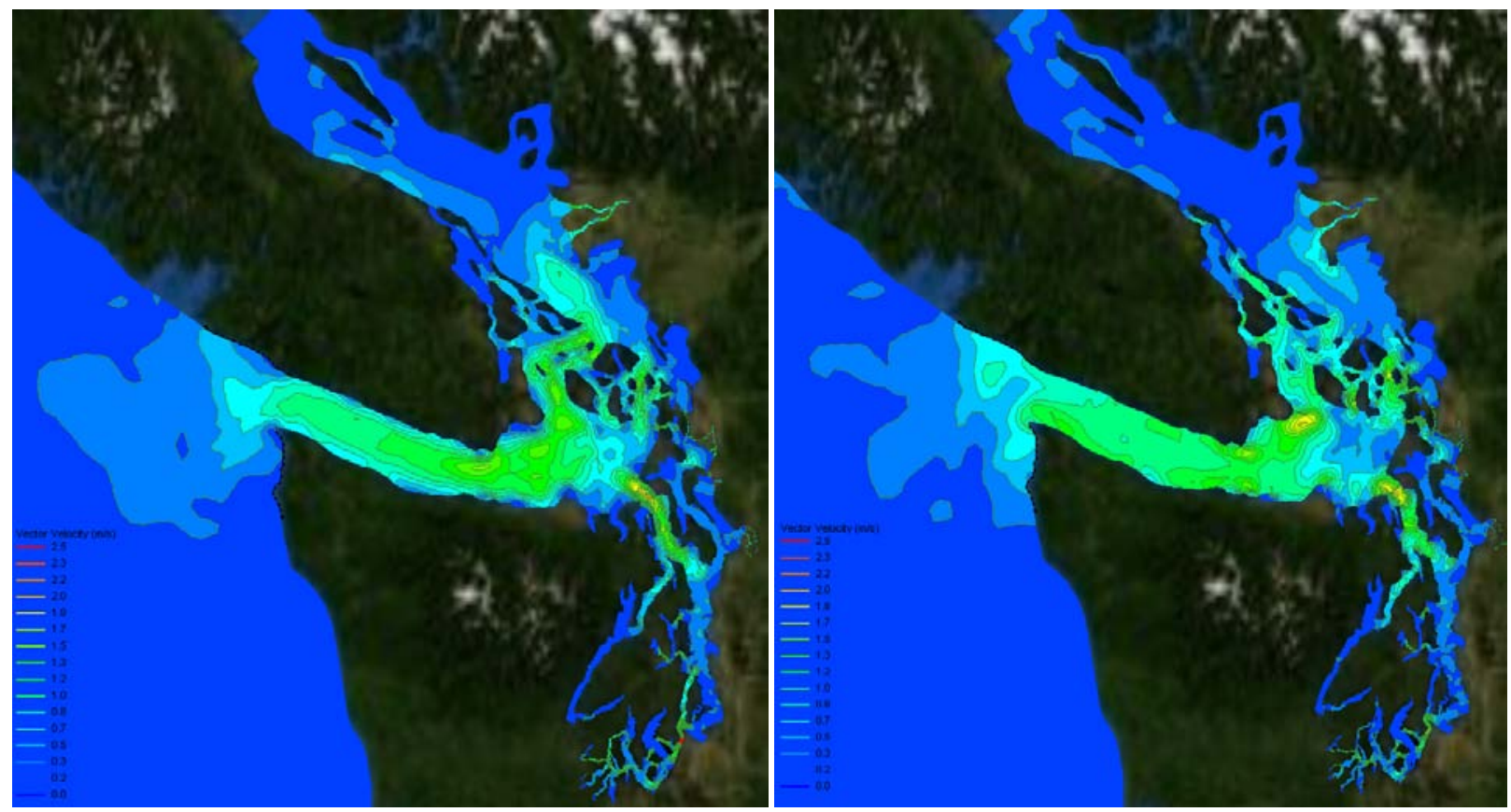

Figure 5. Tidal Currents at Ebb Tide (Left Panel) and Flood Tide (Right Panel) in the Salish Sea and Northwest Coast 


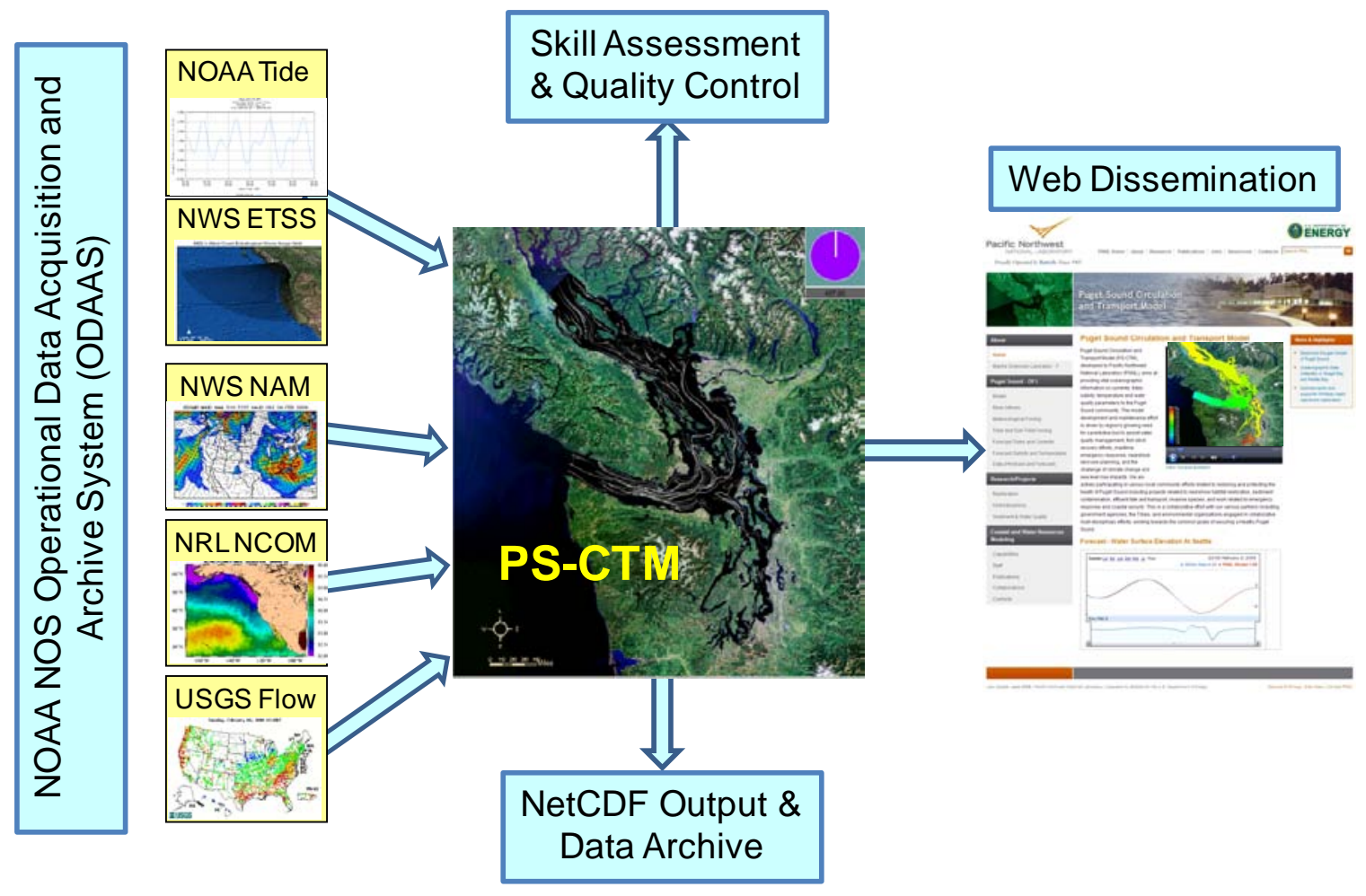

Figure 6. Architecture of the Puget Sound Operational Forecast System 

Appendix A

Conference Proceedings Paper 



\title{
Appendix A Conference Proceedings Paper
}

Proceedings of the $11^{\text {th }}$ International Conference on Estuarine and Coastal Modeling, edited by M. L. Spaulding, American Society of Civil Engineers, Seattle, WA

Puget Sound Operational Forecast System - A Real-time Predictive Tool for Marine Resource Management and Emergency Responses

Zhaoqing Yang ${ }^{1}$, Tarang Khangaonkar ${ }^{1}$

Jared Chase ${ }^{1}$, and Taiping Wang ${ }^{1}$

\begin{abstract}
To support marine ecological resource management and emergency response and to enhance scientific understanding of physical and biogeochemical processes in Puget Sound, a real-time Puget Sound Operational Forecast System (PS-OFS) was developed by the Integrated Coastal Ocean Modeling group (ICOM) of Pacific Northwest National Laboratory (PNNL). PS-OFS employs the state-ofthe-art three-dimensional coastal ocean model and closely follows the standards and procedures established by National Oceanic and Atmospheric Administration (NOAA) National Ocean Service (NOS). PS-OFS consists of four key components supporting the Puget Sound Circulation and Transport Model (PSCTM): data acquisition, model execution and product archive, model skill assessment, and model results dissemination. This paper provides an overview of PS-OFS and its ability to provide vital real-time oceanographic information to the Puget Sound community. PS-OFS supports Pacific Northwest region's growing need for a predictive tool to assist water quality management, fish stock recovery efforts, maritime emergency response, nearshore land-use planning, and the challenge of climate change and sea level rise impacts. The structure of PS-OFS and examples of the system inputs and outputs, forecast results are presented in details.
\end{abstract}

\footnotetext{
${ }^{1}$ Integrated Coastal Ocean Modeling (ICOM), Marine Sciences Laboratory, PNNL, Battelle Seattle Research Center. 1100 Dexter Avenue North, Suite 400, Seattle, WA 98109
} 


\section{Introduction}

Puget Sound is a large fjordal estuary located on the northwest coast of United States. It has several large sub-basins and is bounded by approximately $4,180 \mathrm{~km}$ of complex shorelines. Puget Sound connects the Pacific Ocean via Strait of Juan de Fuca and the Strait of Georgia from British Columbia, Canada. A high resolution three-dimensional Puget Sound circulation and transport model (PSCTM) has been developed by the Coastal Ocean Dynamics \& Ecosystem Modeling group (CODEM) of Pacific Northwest National Laboratory (PNNL) to assist nearshore habitat restoration design, juvenile fish migration and water quality management in Puget Sound. PS-CTM is built using the unstructured-grid Finite Volume Coastal Ocean Model (FVCOM) (Chen et al., 2003) and it has been validated to various data sets of water level, current, salinity and temperature in various sub-basins of the Puget Sound (Yang and Khangaonkar, 2007 \& 2008). As the model becomes more robust through continuous improvements, demand of key oceanographic information generated from the model, such as water levels, currents, salinity and temperature, has been increased significantly. Therefore, it is important that model results are made available to the general public in the Puget Sound community through a real-time operational forecast system.

An operational forecast system (OFS) is defined as a system that is created in response to specific needs, implemented according to well-defined standards, and runs stably, regularly and automatically with quality control (NOAA, 1999, Vincent et al., 2003, Aikman et al., 2008). OFS have been developed in various water bodies in the United States in support of safe and efficient marine navigation, emergency response and ecosystem management (Aikman et al., 2008). These OFSs include five Great Lakes (Erie, Huron, Michigan, Ontario and Superior) and four estuarine and bays (Chesapeake Bay, Galveston Bay, Port of New York and New Jersey, St John's River). The Coastal Survey Development Laboratory (CSDL) of National Ocean Service (NOS) have established a standardized Coastal Ocean Modeling Framework (COMF) to increase the efficiency of the development, transition and operation of real-time coastal and estuarine OFS (Gross et al., 2006; Aikman et al., 2008).

The Puget Sound operational forecast system (PS-OFS) is a real-time operational forecast system which predicts key oceanographic parameters and disseminates model results online in real-time. PS-OFS aims at providing vital oceanographic information to the community in Puget Sound on a continuous and efficient basis. In addition, development of PS-OFS will further enhance our research and understanding of the physical and biogeochemical processes in Puget Sound, as well as the challenge of climate change and sea level rise impacts in Pacific Northwest region. Development of the Puget Sound Operational Forecast System 
(PS-OFS) closely followed the procedures and standards established by NOAA NOS through the development of various OFS in the United States.

\section{Structure of PS-OFS}

PS-OFS primarily consists of four key components around the core of PS-CTM (Figure 1): 1) Data acquisition from NOAA's operational data acquisition and achieve system (ODAAS); 2) Model execution for daily cycle forecast; 3) Model skill assessment; and 4) Dissemination of model results. These four components are executed through the following processes in each cycle of forecast:

- Set environment variables and date module

- Get forecast data from ODAAS

- Reformat data for model input

- Run Puget Sound forecast model

- Conduct model skill assessment

- Extract model results and generate graphics

- Archive model products

- Produce PS-OFS status flags

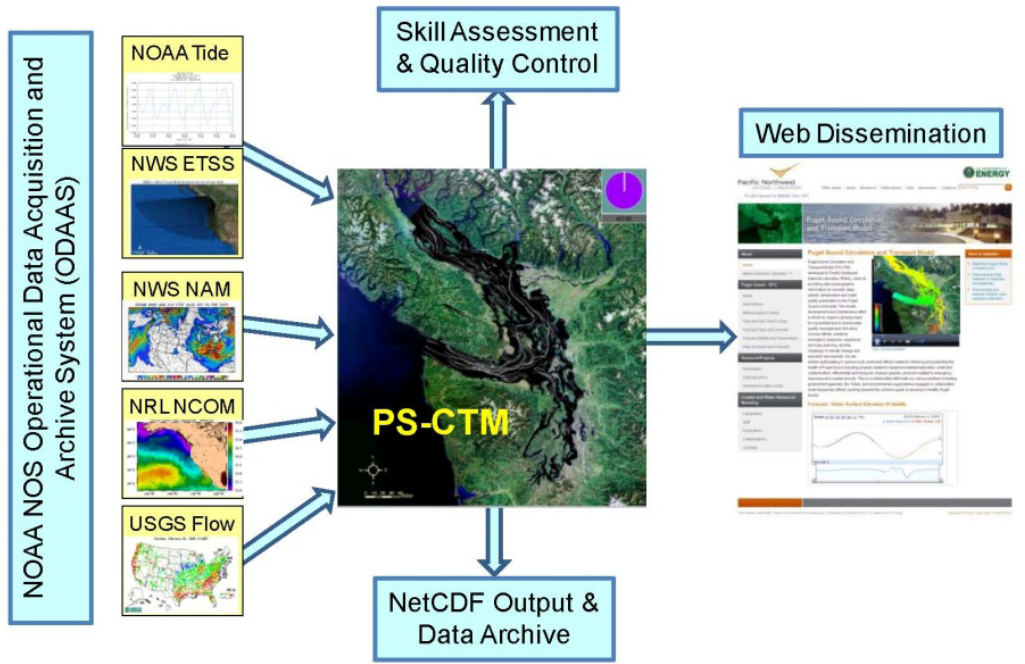

Figure 1 Structure of Puget Sound Operational Forecast System (PS-OFS) 
The core of PS-OFS is the three-dimensional Puget Sound circulation and transport model (PS-CTM). Because of presences of complex coastlines, large tide flats and the density-stratified fjordal circulation in Puget Sound, PS-CTM should be constructed in an unstructured-grid or boundary-fitted-grid framework and have the capability to simulate the wetting/drying processes over tide flats and the baroclinic motion induced by density-stratification. While a number of open-source advanced coastal ocean models are available for this purpose, the Finite Volume Coastal Ocean Model (Chen et al., 2003) is currently selected as the main model for the PS-OFS. FVCOM has been widely used in simulations of circulations in many estuarine and coastal systems (Chen and Rawson, 2005; Weisberg and Zheng, 2006; Isobe and Beardsley, 2006; Aoki and Isobe, 2007; Chen et al., 2008; Yang and Khangaonkar, 2008, 2009, Khangaonkar and Yang, 2009). Figure 2 shows the unstructured-grid of PS-CTM for the entire Puget Sound and the Northwest Straits. 


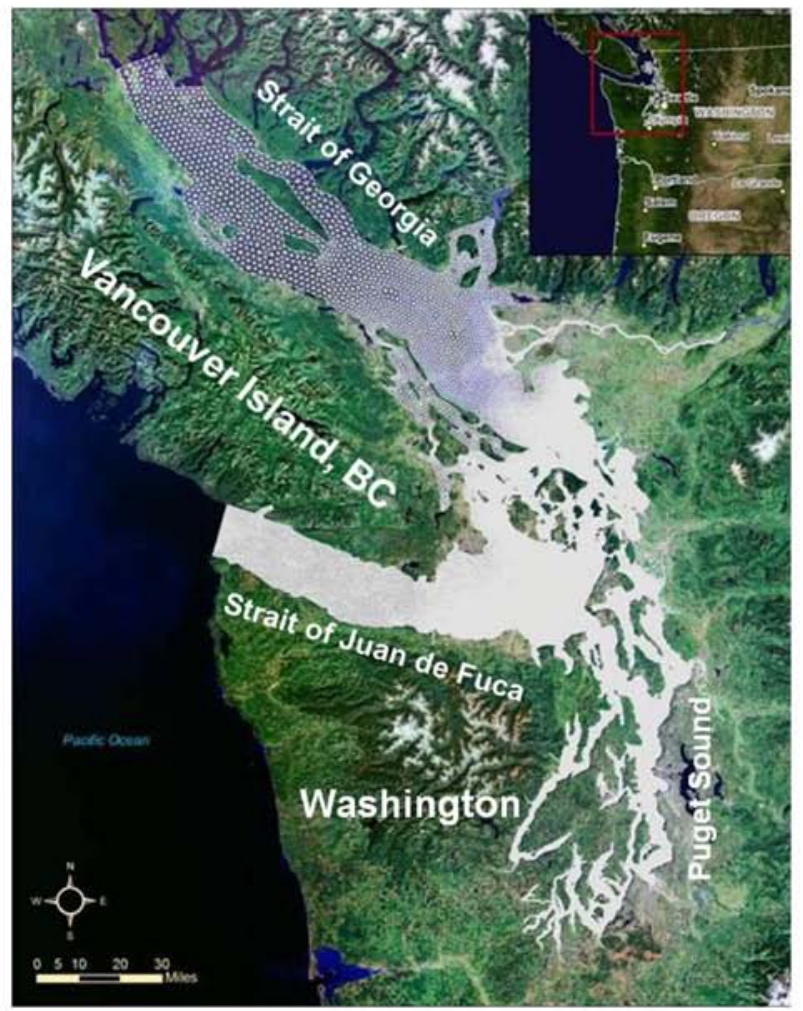

Figure 2 Model Grid for Puget Sound, Strait of Juan de Fuca and Georgia Strait

The model grid of Puget Sound consists of around 110,000 nodes and 210,000 triangular elements with element sizes varying from around 2,500 meters at the open boundaries to the order of 10 meters within estuaries and river channels. Twenty uniform vertical layers were specified in the water column in a sigmastretched coordinate system. PS-CTM simulates water levels, three dimensional currents, salinities and temperatures with forcing of water levels at the open boundaries, meteorological forcing (wind and net heat flux) at the water surface and river inflows at river heads. Details on the development of PS-CTM and its applications are described in Yang and Khangaonkar (2008) and Khangaonkar and Yang (2009). 


\section{Data Acquisition for PS-OFS}

Data acquisition for PS-OFS includes four types of data: 1) open boundary water level; 2) open boundary temperature and salinity; 3) meteorological forcing; 4) river inflows. The first three types of data can be obtained from NOAA NOS's Operational Data Acquisition and Archive System. River inflow data are obtained from United States Geological Survey (USGS) real-time stream gages in the Puget Sound region.

Tide and Subtidal Water Levels

Open boundary water levels consist of tidal and sub-tidal components. Tide is the dominant forcing mechanism for circulation in Puget Sound and the Northwest Straits. Tidal surface elevations along the open boundaries can be specified by either tidal constituents at NOAA real-time water level stations or harmonic tide clock and tide predictor (XTide) based on NOAA tidal prediction algorithms (Flater, 1996). Because there are no NOAA tide stations (and harmonic constituents) on the northern open boundary in British Columbia, in current PSOFS configuration tidal elevations at open boundaries are specified by XTide predictions at Neah Bay at the entrance of the Strait of Juan de Fuca and at Campbell River at the north end of Strait of Georgia (Figure 3). Subtidal water levels at the open boundaries are specified by NOAA National Weather Service's Extra-Tropical Storm Surge (ETSS) model predictions in the US West Coast region. ETSS forecasts sub-tidal water levels every three hours out to 84 hours. 


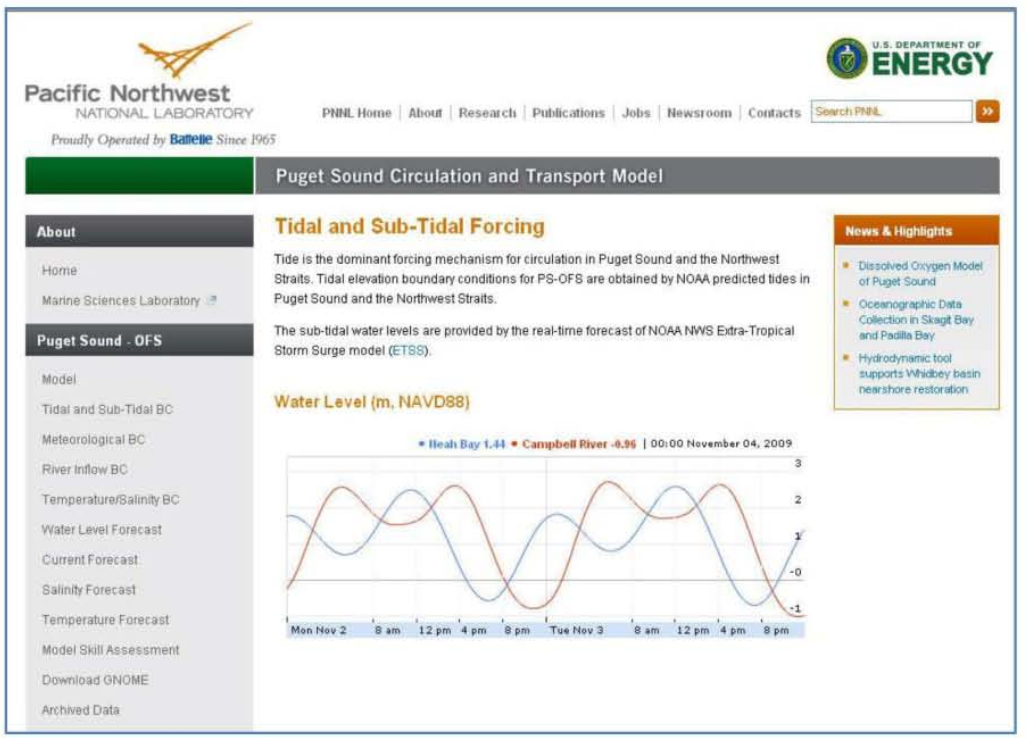

Figure 3 Tidal Elevations (from XTide) at Neah Bay and Campbell River Stations

Salinity and Temperature Open Boundary Conditions

Temperature and salinity values at the model open boundaries of PS-OFS are specified by The Naval Research Laboratory's global Navy Coastal Ocean Model (NCOM) forecast in the Pacific region. NCOM runs daily and forecasts every 3 hours out to 72 hours for water level, current, salinity and temperature at $1 / 8^{\circ}(14$ $\mathrm{km}$ ) resolution (Figure 4) and outputs in NetCDF format. In current PS-OFS configuration, temperature and salinity values at two grid points near PS-CTM open boundaries are obtained from NCOM and used to drive PS-OFS (Figure 4). Time series of NCOM temperature forecast near the surface at model open boundaries are shown in Figure 5. 


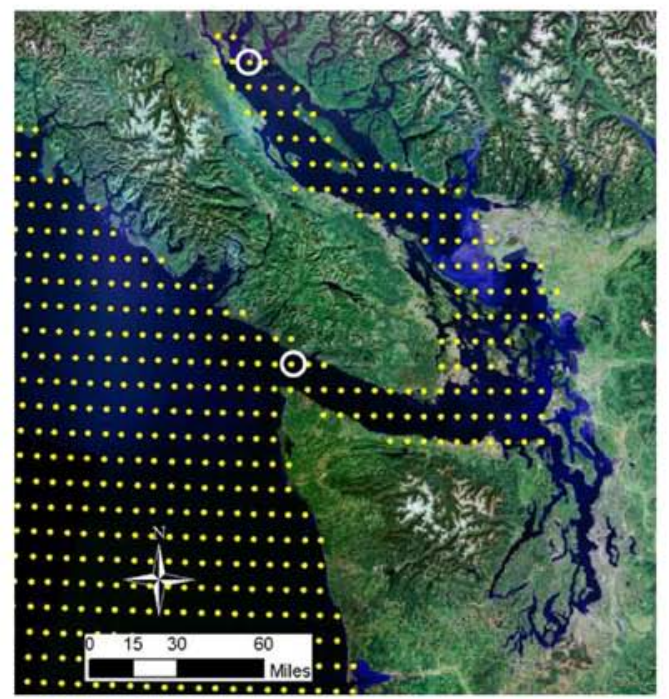

Figure 4 NCOM Grid and for PS-OFS Open Boundary Points (Circled)

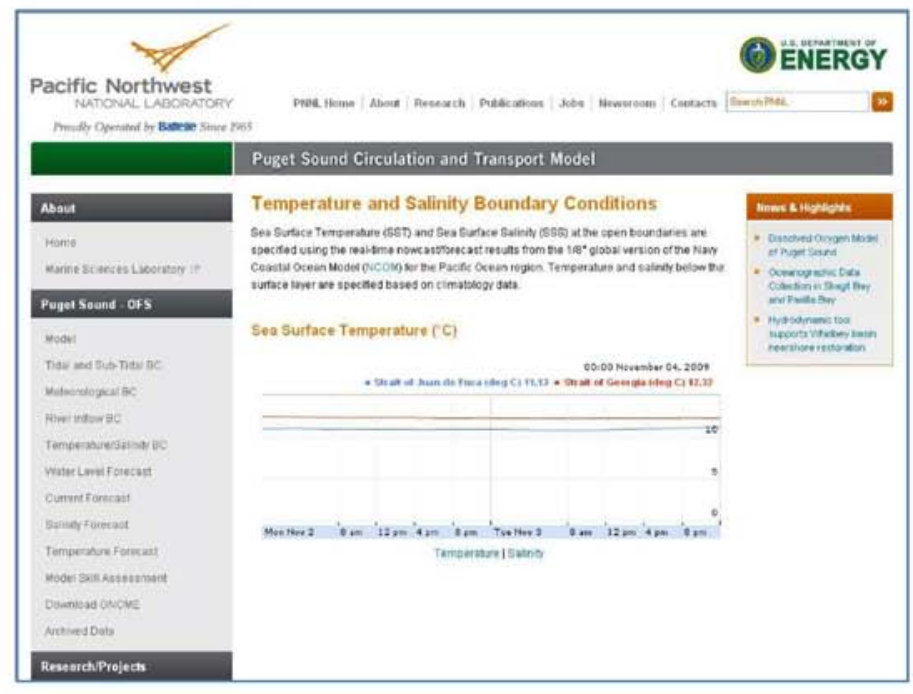

Figure 5 NCOM Temperatures Forecast at PS-OFS Open Boundaries

8 


\section{Wind and Surface Heat Fhx}

Meteorological forcing parameters are required as model input in PS-OFS. NOAA National Weather Service (NWS) North American Model Weather Research Forecast (NAM-WRF) generates real-time meteorological forecast every 3 hours out to 84 hours at $12 \mathrm{~km}$ resolution. The meteorological parameters obtained from NAM-WRF include: 1) wind speed and direction, 2) shortwave and longwave radiations (downward and upward), 3) latent heat flux and 4) sensible heat flux. The surface net heat flux which is required as an input to FVCOM can be directly calculated using shortwave and longwave radiations, latent heat flux and sensible heat flux. Figure 6 shows the wind vector distribution over the Pacific Northwest region at 12:00 pm on November 3, 2009.

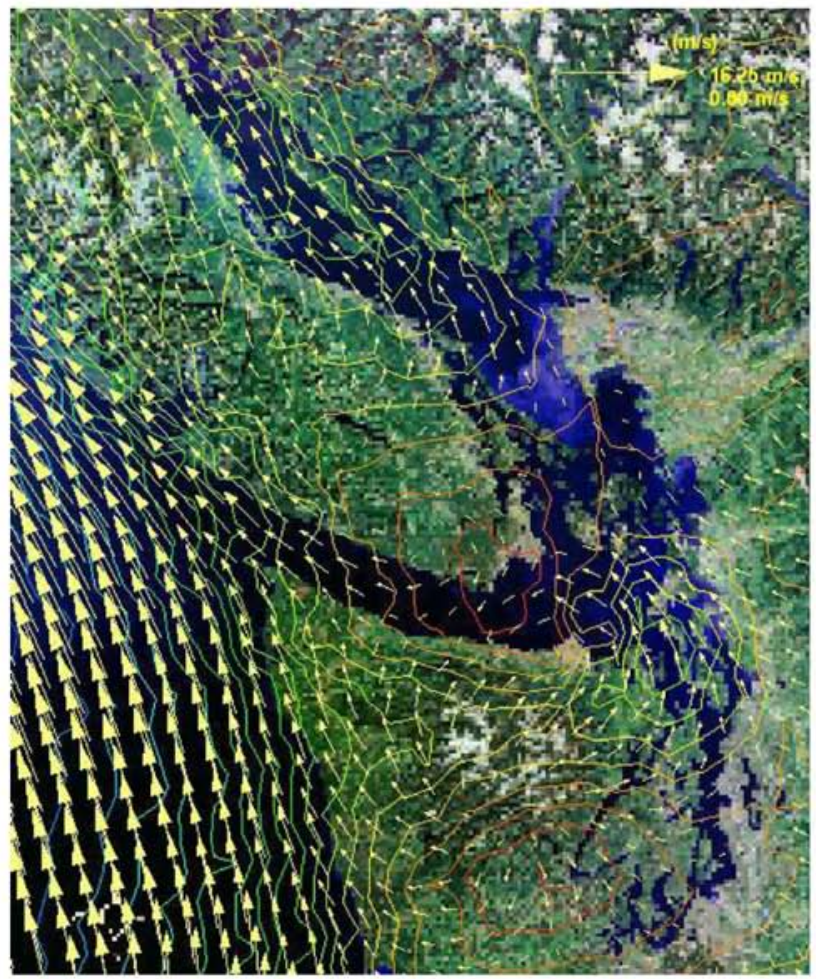

Figure 6 NOAA/NECP NAM-WRF Forecast Wind in Pacific Northwest Region 


\section{River Inflows}

A total of 19 rivers, including the Fraser River from British Columbia of Canada, are currently considered in PS-OFS (Figure 7). Real-time forecasts of river discharges are currently not available or very limited to specific rivers. In current PS-OFS configuration, daily average river inflows based on real-time data for the day before forecast are used as model input. Real-time USGS stream flow gauges exist in 13 major rivers in Puget Sound. Five small rivers in Hood Canal (Big Quilcene, Duckabush, Dosewallips, Hamma Hamm and Tahuya) do not have realtime data and inflows of these rivers are estimated using scaling method based on watershed areas and nearby real-time stream gage data. Real-time data for Fraser River are obtained from Environmental Canada real-time station \#08MF005 at Hope, British Columbia. River inflows in the Whidbey Basin, which receives freshwater discharge from three largest rivers in Puget Sound (Skagit River, Snohomish River and Stillaguamish River) are shown in Figure 8.

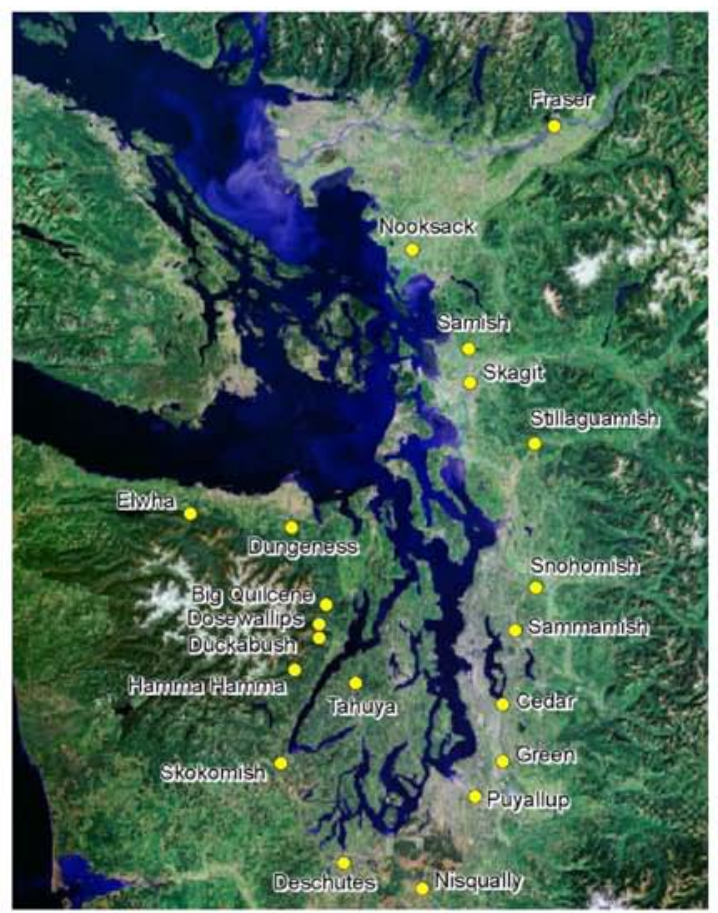

Figure 7 River Locations in Puget Sound and the Northwest Straits 


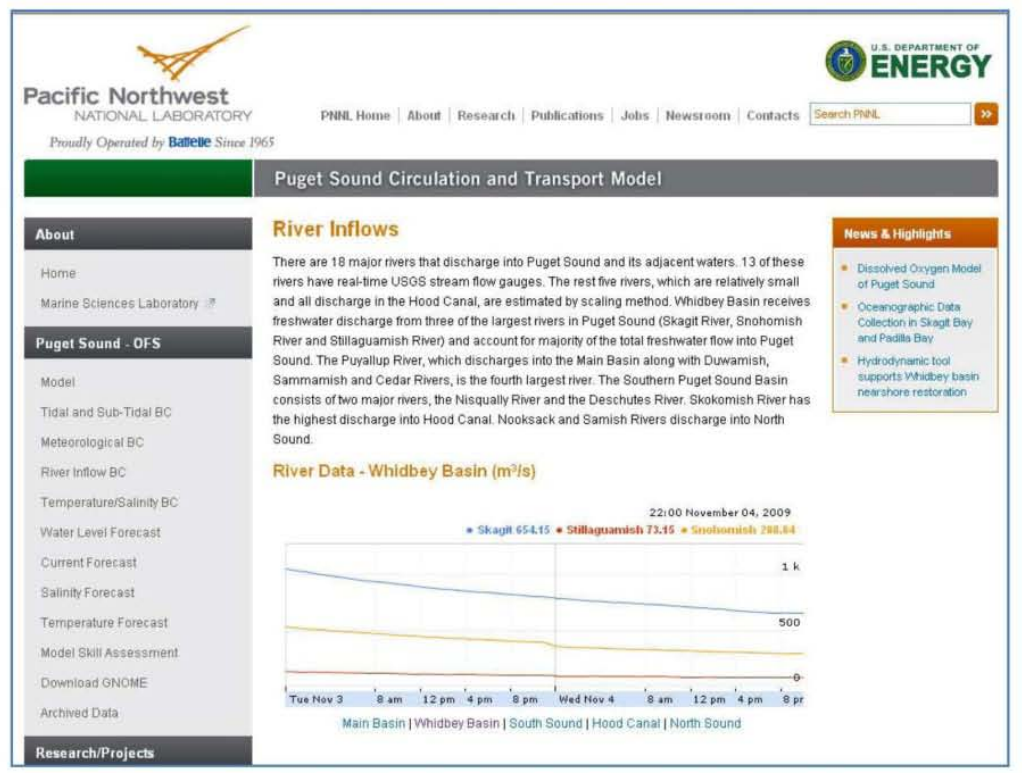

Figure 8 River Inflows in Whidbey Basin of Puget Sound

\section{Forecast Results and Web Dissemination}

PS-OFS currently operates daily and forecasts every hour out to 48 hours. A status message with quality control flags and product links is generated automatically everyday at the end of each forecast cycle. Forecast results, such as water level, current, temperature and salinity, are displayed online at selected locations in Puget Sound. These locations include all the real-time stations at NOAA's Center for Operational Oceanographic Products and Services (CO-OPS) and NOAA's Physical Oceanographic Real-Time System (PORTS) stations in Puget Sound. Forecast water levels are compared to six NOAA CO-OPS real-time stations at Port Angeles, Friday Harbor, Cherry Point, Port Townsend, Seattle and Tacoma. Example of water level forecast with comparison to NOAA real-time data from November 2 to 3, 2009 at Seattle Station is shown in Figure 9. 


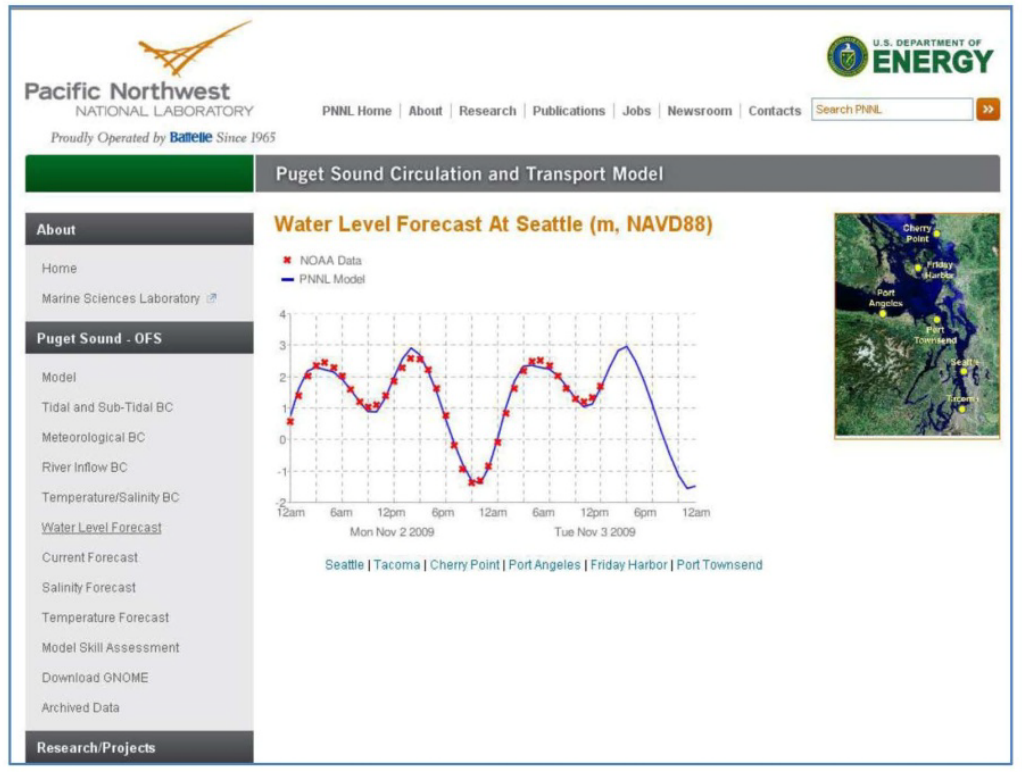

Figure 9 Water Level Forecast at Seattle

Currently, there are no NOAA real-time current and salinity data available in Puget Sound. However, two NOAA PORTS stations, Tacoma and Cherry Point, have real-time water temperature data. Examples of current forecast at Elliott Bay, salinity forecast at Skagit Bay and temperature forecast at Tacoma from November 2 to 3, 2009 are shown in Figures 10, 11 and 12 respectively.

Model skill assessment is also conducted for PS-OFS based on observed water level data. NOAA NOS has established a set of criteria for model skill assessment (NOAA, 2003; Zhang et al.,, 2006; Patchen, 2008). Various criteria can be selected and used to evaluate the performance of a coastal hydrodynamic model based on the objective of the modeling system and user requirements. Due to the limitation of observation in Puget Sound, only root mean square error (RMSE) for water levels is conducted for PS-OFS (Figure 13). The overall RMSEs are in the range of 0.1 to $0.2 \mathrm{~m}$. Harmonic analysis indicated errors for mean water surface elevations have significant contribution to the total RMSEs. Therefore, model skills for water levels can be further improved through improvement of sub-tidal water levels at open boundaries. 


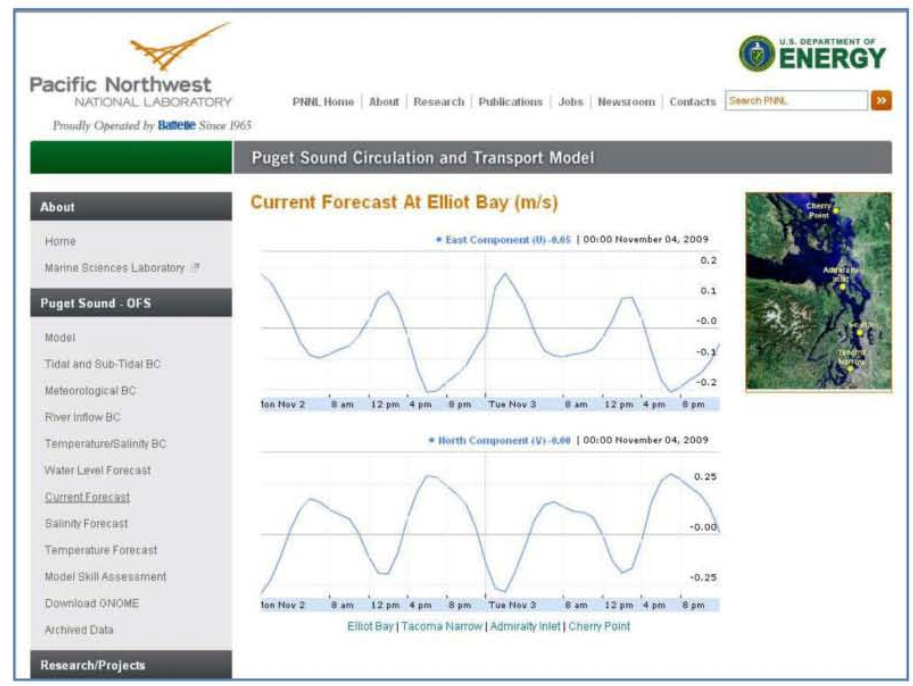

Figure 10 Current Forecast at Elliott Bay Station

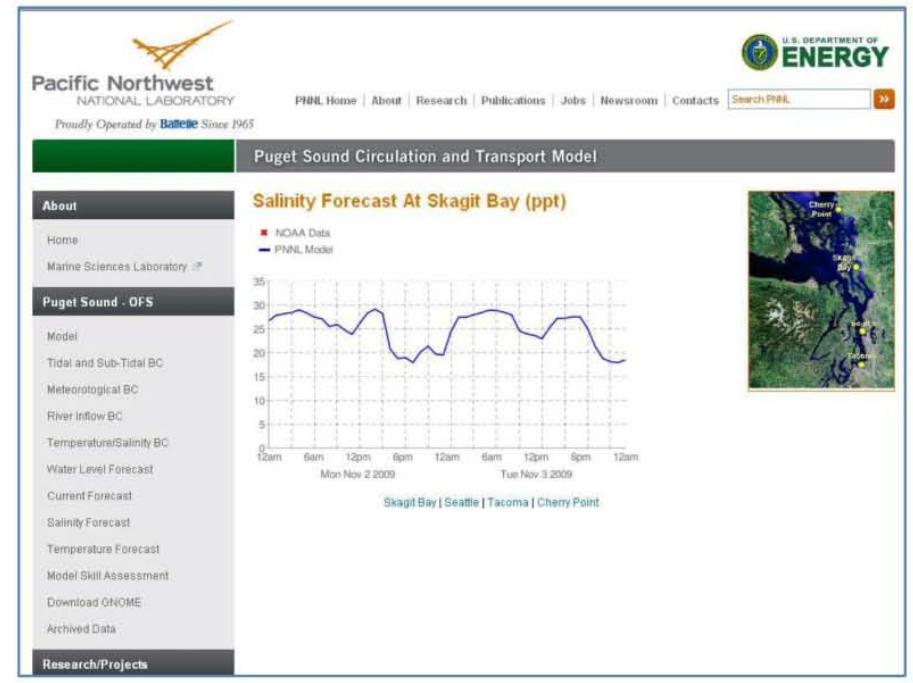

Figure 11 Salinity Forecast at Skagit Bay Station 


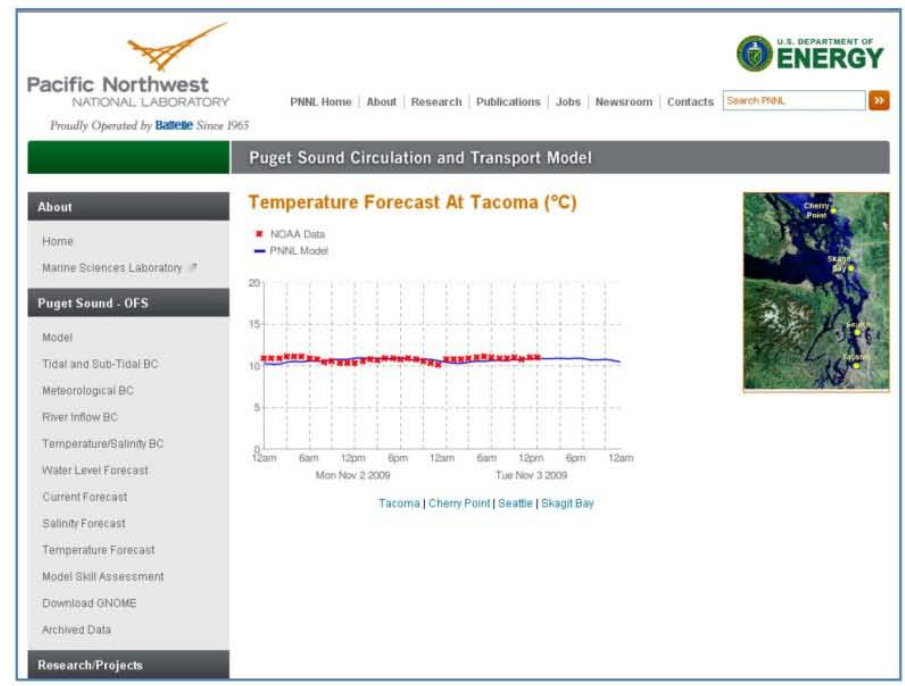

Figure 12 Temperature Forecast at Tacoma Station

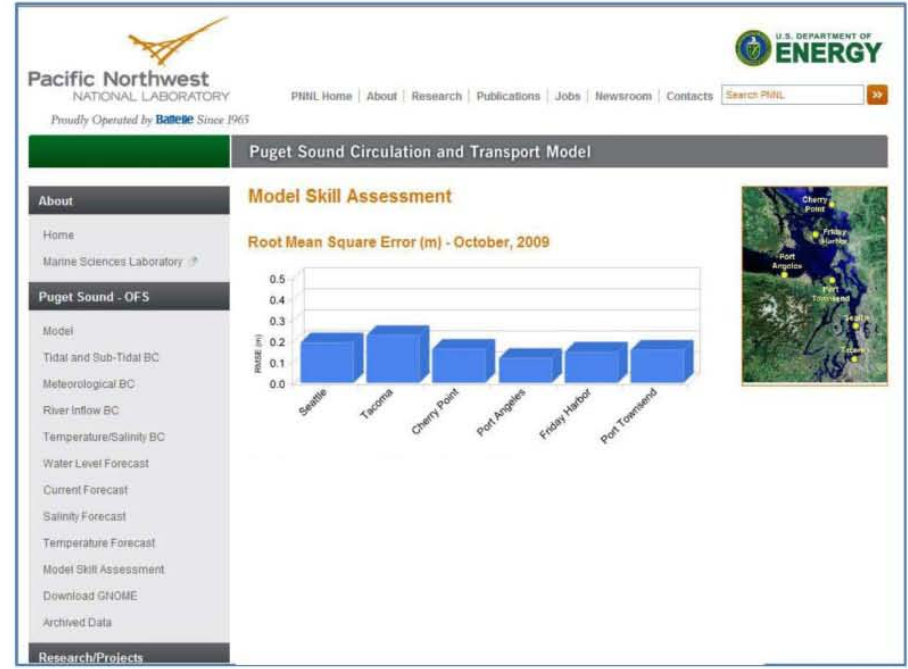

Figure 13 Model Skill Assessment of PS-OFS - Water Level

14 


\section{Summary}

A real-time Puget Sound Operational Forecast System (PS-OFS) has been developed using the unstructured-grid Puget Sound Circulation and Transport Model (PS-CTM). PS-OFS is driven by XTides and NOAA ETSS sub-tidal water levels on the open boundaries. Salinity and temperature open boundary conditions are provided by the Office of Naval Research's Navy Coastal Ocean Model (NCOM). The meteorological inputs are obtained from the real-time forecast of NOAA/NCEP NAM-WRF. River inflows are provided by the USGS real-time stream gage data. Model open boundaries are specified at the entrance of Strait of Juan de Fuca and the north end of Strait of Georgia. The development of PS-OFS closely follows NOAA's operational forecast standards and procedures such as model inputs, quality control, model skill assessment, data archive and web dissemination. PS-OFS is currently under real-time testing and continuous improvement. The performance of PS-OFS demonstrates its ability to provide vital real-time oceanographic information to the Puget Sound community, in response to the region's growing need for a predictive tool to assist marine resources management, emergency response, and enhance fundamental oceanographic research in Puget Sound.

While the PS-OFS is up and running in real-time operation, further improvements of PS-OFS are possible. Future work for the system improvements includes:

- Inclusion of skill assessments for currents, salinity and temperature and expansion of the skill metrics such CF, POF and NOF.

- Generation of skill assessment on a monthly basis

- Inclusion more real-time observations from The Northwest Association of Networked Ocean Observing Systems (NANOOS).

- Improvement of meteorological forcing by including the effects of atmospheric pressure anomaly and feedback of water temperature.

- Inclusion of nowcast at six-hour cycle as needed. 


\section{Acknowledgements}

The authors would like to thank Frank Aikman, Rich Patchen, Eugene Wei, Edward Myers, John Kelley, Aijun Zhang, Mark Vincent, Jiantao Xu and Greg Mott of NOAA NOS for their support during the development of the PS-OFS. This work is funded by Laboratory Directed Research and Development grants of PNNL. We would also like to acknowledge PNNL's Bill Peterson who has provided on-going encouragement and support in connection with use of PS-OFS for marine-time emergency response.

\section{References}

Aikman, F. III, M. Vincent and R. Patchen, 2008. Development and Evaluation of Operational Forecast System for the Coastal and Estuarine Enviornment in NOAA's National Ocean Service. In: Proceedings of the 10th International Conference, edited by M. L. Spaulding. American Society of Civil Engineers, Newport, RI. pp 671-684

Aoki, K., Isobe, A., 2007. Application of finite volume coastal ocean model to hindcasting the wind-induced sea-level variation in Fukuoka bay. J. Oceanogr. 63 (2), 333-339.

Chen, C., H. Liu, R. C. Beardsley, 2003. An unstructured, finite-volume, threedimensional, primitive equation ocean model: application to coastal ocean and estuaries. J. Atm. \& Oceanic Tech., 20, 159-186.

Chen, C., Rawson, M., 2005. An ecosystem management model system for the Satilla River Estuary, Georgia. Oceans, 2005. In: Proceedings of MTS/IEEE, vol. 1, pp. 622-632.

Chen, C., Xue, P., Ding, P., Beardsley, R.C., Xu, Q., Mao, X., Gao, G., Qi, J., Li, C., Lin, H., Cowles, G., Shi, M., 2008. Physical mechanisms for the offshore detachment of the Chanjiang diluted water in the East China Sea. J. Geophys. Res. 113, C02002, doi: 10.1029/2006JC003994.

Flater, D., 1996. A brief introduction to XTide. Limix Journal, 32, 51-57.

Gross, T.F., H. Lin, Z. Bronder and M. Vincent. 2006. The coastal ocean modeling framework: COMF. NOAA Technical Report NOS CS 22, $145 \mathrm{pp}$.

Isobe, A., Beardsley, R.C., 2006. An estimate of the cross-frontal transport at the shelf break of the East China Sea with the Finite Volume Coastal Ocean Model. J.Geophys. Res. 111, C03012.

Khangaonkar, T. and Z. Yang, 2009. A high resolution hydrodynamic model of Puget Sound to support nearshore restoration feasibility analysis and design. Accepted for publication in Journal of Ecological Restoration. 
NOAA, 1999. NOS procedures for developing and implementing operational nowcast and forecast systems for PORTS. NOAA Technical Report NOS CO-OPS 20,33p.

NOAA, 2003. NOS standards for evaluating operational nowcast and forecast hydrodynamic model systems. NOAA Technical Report NOS CS 17,33p

Patchen, R., 2008. Establishment of a Delaware Bay Model Evaluation Environment. In: Proceedings of the 10th International Conference, edited by M. L. Spaulding. American Society of Civil Engineers, Newport, RI. pp 783-818.

Vincent, M., K. Hess and J. Kelley, 2003. NOS procedures for developing and implementing operational nowcast and forecast hydrodynamic model systems. NOAA Technical Report NOS CO-OPS 39, 17p.

Yang, Z., and T. Khangaonkar. 2007. Development of a Hydrodynamic Model of Puget Sound and Validation and Application for the Northwest Straits. PNNL-17161, Pacific Northwest National Laboratory, Richland, WA

Yang, Z. and T. Khangaonkar, 2008. Development of a 3D Unstructured Circulation Model of Puget Sound. In: Proceedings of the 10th International Conference, M. L. Spaulding, ed., American Society of Civil Engineers, Newport, RI. pp 1-17.

Yang, Z., and T. Khangaonkar, 2009. Modeling tidal circulation and stratification in Skagit River Estaury using an unstructured Grid Ocean model. Ocean Modell. 28, 34-49, doi:10.1016/j.ocemod 2008.07.004

Weisberg, R.H., Zheng, L., 2006. Circulation of Tampa Bay driven by buoyancy, tides, and winds, as simulated using a finite volume coastal ocean model. J. Geophys. Res. 111, C01005, doi:10.1029/2005JC003067.

Zhang, A., K. W. Hess, E. Wei, E. Myers, 2006. Implementation of model skill assessment software for water level and current in tidal regions. NOAA Technical Report NOS CS 24, 33p. 

Appendix B

\section{Submitted Journal Article}





\section{Appendix B}

\section{Submitted Journal Article}

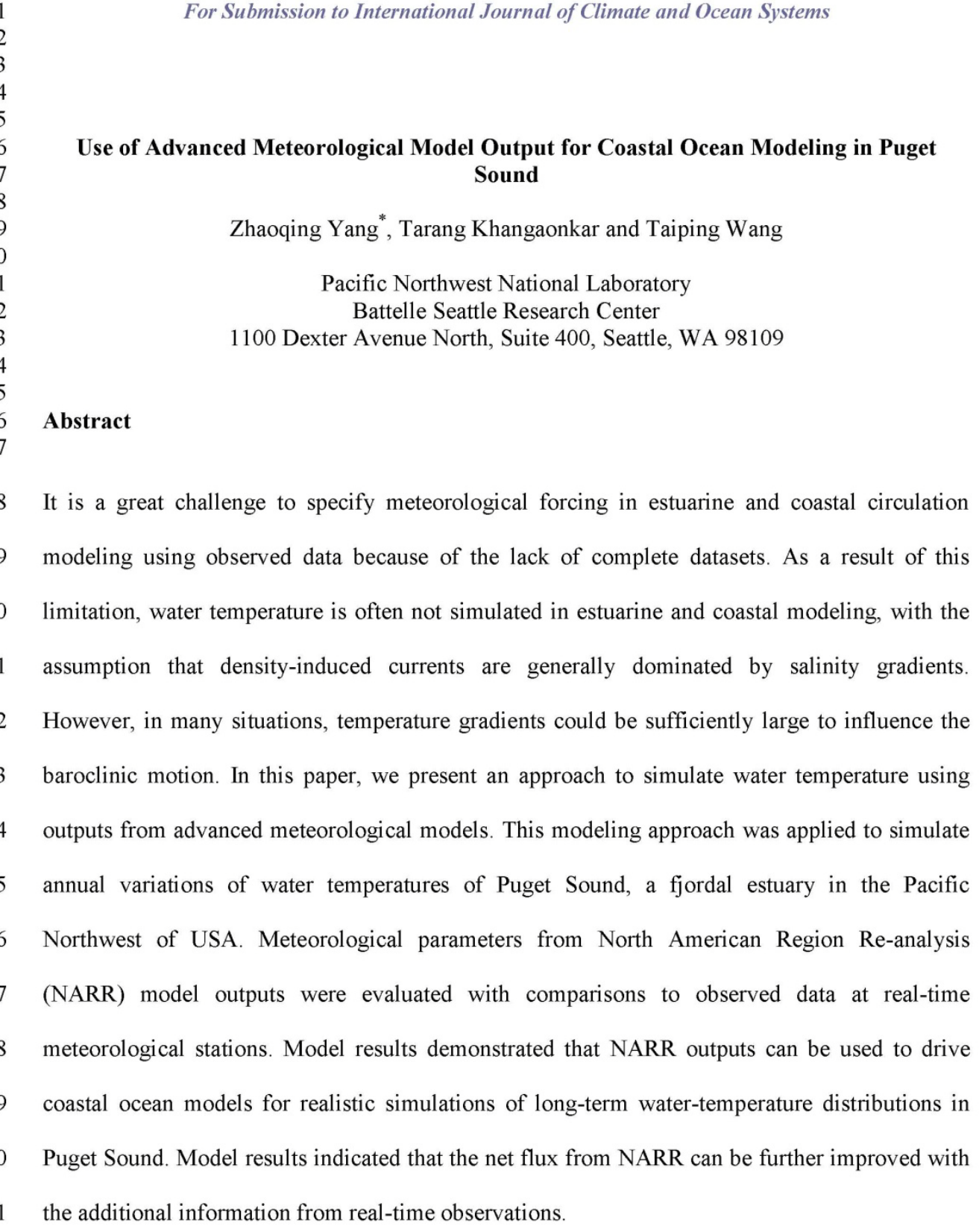

Use of Advanced Meteorological Model Output for Coastal Ocean Modeling in Puget Sound

Zhaoqing Yang*, Tarang Khangaonkar and Taiping Wang

Pacific Northwest National Laboratory

Battelle Seattle Research Center

1100 Dexter Avenue North, Suite 400, Seattle, WA 98109

\begin{abstract}
It is a great challenge to specify meteorological forcing in estuarine and coastal circulation modeling using observed data because of the lack of complete datasets. As a result of this limitation, water temperature is often not simulated in estuarine and coastal modeling, with the assumption that density-induced currents are generally dominated by salinity gradients. However, in many situations, temperature gradients could be sufficiently large to influence the baroclinic motion. In this paper, we present an approach to simulate water temperature using outputs from advanced meteorological models. This modeling approach was applied to simulate annual variations of water temperatures of Puget Sound, a fjordal estuary in the Pacific Northwest of USA. Meteorological parameters from North American Region Re-analysis (NARR) model outputs were evaluated with comparisons to observed data at real-time meteorological stations. Model results demonstrated that NARR outputs can be used to drive coastal ocean models for realistic simulations of long-term water-temperature distributions in Puget Sound. Model results indicated that the net flux from NARR can be further improved with
\end{abstract} the additional information from real-time observations.

" Corresponding Author. zhaoqing.yang@apnl.gov; 206-528-3057 


\section{$1 \quad 1$ Introduction}

2 Estuarine and coastal circulation is primarily subject to three types of forcing: tides, river

3 inflows, and meteorological conditions that include surface wind stress and heat exchanges.

4 Tidal forcing is generally well defined in coastal modeling. Many observations and accurate

5 predictions are available to specify open boundary conditions (Foreman, 1978; Flater, 1996;

6 Mark et al., 2004). In the United States, river inflow data are also well established by the United

7 States Geological Survey (USGS) stream flow network in all the major rivers. However,

8 meteorological forcing data are often limited and have high uncertainties in coastal and estuarine

9 modeling, in comparison to tides and river inflows. In many research and practical modeling

10 applications, meteorological forcing mechanisms are either specified with limited data sets or

11 even neglected. In particular, simulating water temperatures in estuarine and coastal waters

12 remains a big challenge, especially when seasonal and annual long-term simulations are required

13 for large coastal and estuarine water bodies. Over the last decade, rapid development of

14 advanced meteorological models has greatly improved the accuracy of predicted meteorological

15 parameters. The most widely used comprehensive meteorological models include 1) fifth-

16 generation Pennsylvania State University-National Center for Atmospheric Research Mesoscale

17 Model (MM5) (Dudhia, 1993; Grell et al., 1995, Charles and Colle, 2009); 2) National Oceanic

18 and Atmospheric Administration (NOAA) National Centers for Environmental Prediction

19 (NCEP) Weather Research and Forecasting North American Model (WRF-NAM) (Black, 1994;

20 Rogers et al., 1996; Michalakes et al., 2004); and 3) NOAA NCEP North American Regional

21 Analysis (NARR) (Lin et al., 1999; Mesinger et al., 2003, 2006).

22 
1 The availability of the continuous and systematic meteorological data from the advanced

2 meteorological model outputs is of major benefit to the estuarine and coastal ocean modeling

3 community. Many studies have used meteorological model outputs to drive the coastal ocean and

4 estuarine models for coastal environmental predictions. Gomez-Gesteira et al. (2006) used long-

5 term forecast of winds to calculate the Ekman transport along the Galician coast northwest of

6 Spain from November 1999 to October 2005. Chen et al. (2005) applied MM5 data to hindcast

7 the ocean surface forcing fields over the Gulf of Main and Georges Bank region. WRF-NAM is a

8 state-of-the-art next-generation mesoscale numerical weather prediction system that serves both

9 the atmospheric research and operational forecasting communities. Lopes et al. (2009) coupled

10 WRF output to model the temperature and the phytoplankton distributions at the Aveiro near the

11 coastal zone in Portugal. Koracin et al. (2004) used the month-long MM5 outputs to investigate

12 perturbations of topographically forced wind stress and wind stress curl during upwelling-

13 favorable winds along the California and Baja California coasts during June 1999. Qi et al.

14 (2009) applied WRF wind fields to drive the unstructured finite-volume surface wave model

15 FVCOM-SWAVE to simulate wind-induced surface waves on the U.S. northeast shelf with a

16 central focus in the Gulf of Maine and the New England Shelf. Surface winds are a major forcing

17 mechanism of circulation of the coastal oceans and estuaries. Otero and Ruiz-Villarreal (2008)

18 compared winds from NARR (NCEP Reanalysis 1 and 2) and MM5 to observations for the

19 coastal region around northwest and north Iberia during a typical autumn downwelling period.

20 Signell et al. (2004) evaluated the quality of wind outputs from four meteorological models for

21 oceanographic modeling in semi-enclosed basins and concluded that high-resolution, non-

22 hydrostatic meteorological models offer significant advantages for driving oceanographic

23 modeling. Capet et al. (2004) also showed that the spatial structure of nearshore wind analyzed 
1 from high-resolution atmospheric model COAMPS has a strong influence on the patterns of

2 upwelling circulation and biogeochemical processes in the coastal regions. More recently, Huang

3 et al. (2010) demonstrated that a three-dimensional (3-D) hydrodynamic model of Lake Ontario

4 can successfully reproduce the lake surface temperature and stratification using observed and

5 atmospheric forecast forcing.

6

7 In this paper, we present an approach of linking meteorological model outputs such as NARR to

8 a costal ocean model to simulate water temperatures. This was accomplished over Puget Sound,

9 a large fjordal estuary in the Pacific Northwest coast. Comparisons of model results to observed

10 data at locations in the main stem of the estuary are presented. This study demonstrated that

11 while there is room for improvement, advanced meteorological model outputs from NARR

12 (wind, solar radiation and surface heat fluxes) can be used to drive coastal ocean modeling to

13 simulate water temperature diurnal to seasonal variations in Puget Sound.

14

152 Methodology

$16 \quad 2.1$ Study Domain - Puget Sound

17 Puget Sound is a large fjordal estuary located in the Pacific Northwest coast of North America

18 (Figure 1). Circulation in Puget Sound is dominated by tides that propagate into Puget Sound and

19 further north to the Strait of Georgia from the Pacific Ocean through the Strait of Juan de Fuca.

20 The Strait of Juan de Fuca is a high-tidal energy waterway that connects the estuarine system to

21 the eastern Pacific Ocean and is the main outlet of freshwater to the Pacific Ocean. The large

22 freshwater discharge from the Fraser River in the Strait of Georgia in British Columbia affects

23 stratification and currents in the adjacent waters of the Strait of Juan de Fuca and Puget Sound 
1 (Moore et al., 2008; Newton, 1995; Ebbesmeyer et al., 1989). The circulation in Puget Sound

2 shows distinct fjordal characteristics with mean outflow in the thin surface layers and inflow

3 right below the pycnocline. This is caused by the strong influence of numerous freshwater

4 discharges from rivers in the sub-basins of Puget Sound. The circulation in Puget Sound is also

5 known to be affected by winds and surface heat flux (Thomson et al., 2007; Tinis et al., 2006;

6 Holbrook and Halpern 1982).

7

$8 \quad 2.2$ Hydrodynamic Model (FVCOM)

9 Puget Sound consists of over 4,100 km of complex shoreline, many islands, interconnected water

10 waterways, and sub-basins. To represent these complex geometric features accurately and

11 efficiently, we selected a 3-D unstructured-grid, finite-volume coastal ocean model (FVCOM)

12 developed by Chen et al. (2003). FVCOM is a 3-D hydrodynamic model that can simulate tide,

13 density-driven, and meteorological forcing-induced circulation in an unstructured, finite-element

14 framework. FVCOM solves the 3-D momentum, continuity, temperature, salinity, and density

15 equations in an integral form. A sigma-stretched coordinate system was used in the vertical plane

16 to better represent the irregular bathymetry. The model employs the Mellor Yamada level 2.5

17 turbulent closure scheme for vertical mixing and the Smagorinsky scheme for horizontal mixing.

18 One advanced feature in FVCOM is that meteorological forcing can be directly specified using

19 outputs from meteorological models.

20

21 The governing equations for continuity and momentum in FVCOM are in the following forms: 


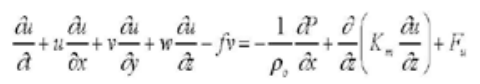

$$
\frac{\hat{\alpha}}{\partial}+u \frac{\partial}{\partial x}+v \frac{\partial}{\partial y}+w \frac{\hat{\partial}}{\partial z}+f u=-\frac{1}{\rho_{0}} \frac{\partial^{P}}{\partial y}+\frac{\partial}{\partial z}\left(K_{n} \frac{\partial u}{\partial z}\right)+F_{z}
$$

$$
\frac{\partial P}{\partial z}=-\rho g
$$

5 where $(x, y, z)$ are the east, north, and vertical axes in the Cartesian coordinates; $(u, v, w)$ are the

6 three velocity components in the $x, y$, and $z$ directions; $\left(F_{u}, F_{v}\right)$ are the horizontal momentum

7 diffusivity terms in the $x$ and $y$ directions; $K_{m}$ is the vertical eddy viscosity coefficient; $\rho$ is

8 density; $P$ is pressure; and $f$ is the Coriolis parameter.

9

10 The 3-D transport equations for temperature and salinity are:

11

12

$$
\frac{\partial T}{\partial t}+u \frac{\partial T}{\partial x}+v \frac{\partial T}{\partial y}+w \frac{\partial T}{\partial z}=\frac{\partial}{\partial z}\left(K_{h} \frac{\partial T}{\partial z}\right)+F_{T}
$$

$$
\frac{\partial S}{\partial t}+u \frac{\partial S}{\partial x}+v \frac{\partial S}{\partial y}+w \frac{\partial S}{\partial z}=\frac{\partial}{\partial z}\left(K_{h} \frac{\partial S}{\partial z}\right)+F_{S}
$$

14 where $T$ and $S$ are temperature and salinity, $K_{h}$ is the vertical eddy diffusivity coefficient, and

$15\left(F_{T}, F_{S}\right)$ are the horizontal thermal and salt diffusivity terms.

16 Temperature and salinity are related to density through the equation of state:

17 
2 The bottom friction is described by the quadratic law. FVCOM has been applied to study various

3 physical processes in estuarine and coastal waters (Chen et al., 2006; Weisberg and Zheng, 2006;

4 Isobe and Beardsley, 2006; Frick et al., 2007; Huang et al., 2008; Chen et al., 2008; Yang and

5 Khangaonkar, 2008, 2009; Yang et al., 2010, Foremen et al., 2009; Shore, 2009).

6

$7 \quad 2.3 \quad$ Model Grid

8 An unstructured grid of FVCOM for Puget Sound was generated using bathymetric data from

9 Puget Sound Digital Elevation Model (Finlayson et al., 2000). To simulate the circulation in

10 Puget Sound and the northwest straits properly, there is a need to extend the study domain from 11 the entrance of the Strait of Juan de Fuca to the north end of Georgia Strait in Canada. The model 12 open boundaries were specified far enough from the entrance of Admiralty Inlet to minimize the 13 effects of the open boundary conditions on Puget Sound. The western extent of the Strait of Juan 14 de Fuca was selected for the western open boundary. Because of the presence of the San Juan 15 Islands and waterways, the northern open boundary line was specified at the north end of 16 Georgia Strait. While tide flats play important role in the estuarine circulation dynamics near the 17 estuarine mouth, the primary objective of this modeling study was to investigate the performance 18 of meteorological model outputs as surface forcing in a coastal ocean model for water 19 temperature simulations. Therefore, the effects of shallow tide flats were not included in this 20 model configuration, and the minimum water depth was set to $4.0 \mathrm{~m}$ below NAVD88. For 21 modeling efficiency, model grid cell sizes vary from $3,000 \mathrm{~m}$ at the open boundaries to around $22350 \mathrm{~m}$ in estuaries and bays. The average cell size is about $1,600 \mathrm{~m}$ considering that the entire 
1 model domain and the average cell size in Puget Sound is $800 \mathrm{~m}$. Thirty vertical layers with

2 uniform thickness were specified in the water column in a sigma-stretched coordinate system.

3

$4 \quad 2.4$ Model Open Boundary Conditions

5 The Puget Sound hydrodynamic model has two open boundaries: one is located at the entrance

6 of the Strait of Juan de Fuca, and the other is at north end of Georgia Strait. Tidal elevations are

7 specified along the open boundaries using XTide predictions (Flater, 1996). Tidal elevations

8 were assumed to be the same across the open boundaries and were specified at 15 -minute

9 intervals. Tidal range and mean elevation at the north end of Georgia Strait are greater than that

10 at the entrance of Strait of Juan de Fuca because tides are amplified as the tides propagate from

11 the Strait of Juan de Fuca into Puget Sound and Georgia Strait. Salinity and temperature open

12 boundary conditions were specified based on the monthly profiles collected by the Department

13 of Fisheries and Oceans, Canada, near the entrance of the Strait of Juan de Fuca and north

14 Georgia Strait for year 2006. Salinity and temperature profiles were assumed to be the same at

15 all the grid nodes along each open boundary.

16

17 Nineteen major rivers (including the Fraser River) that discharge into Puget Sound and the

18 Straits were considered in the model. Most of the river inflow data were obtained from the USGS

19 real-time stream flow gauges. For rivers that had no real-time measurements, river inflows were

20 estimated by the Washington Department of Ecology using a scaling method based on watershed

21 areas. All river inflows inside Puget Sound show similar patterns with high flood events

22 occurring in the late fall and winter periods and relatively low flow in the late spring and early

23 summer. In contrast, the Fraser River inflow, which is significantly higher than the rest of river 
1 inflows into Puget Sound and the Straits, shows a very different seasonal distribution pattern

2 with high flow in the late spring and summer and low flow in the fall and winter.

3

\section{Model Simulations}

\section{$5 \quad 3.1 \quad$ Simulations with Direct NARR Forcing}

6 The focus of this paper is on the water temperature simulations using forcing from 7 meteorological model outputs as opposed to relying on measured data from meteorological 8 stations. Model results for tide, current, and salinity predictions have been presented in Yang 9 et al. (2010) and are not repeated here. It is a great challenge to simulate the temperature 10 distributions in estuaries and coastal waters such as Puget Sound compared to tide and current

11 simulations because of the uncertainty associated with meteorological forcing and the 12 complexity of density-induced baroclinic motion.

13

14 To simulate the temperature distribution in Puget Sound, wind stress and net heat flux are 15 required to specify surface boundary conditions at the water surface. The meteorological input 16 parameters for FVCOM include 1) wind speed and direction, 2) shortwave and longwave 17 radiation (downward and upward), and 3) latent heat flux and sensible heat flux. There are 18 generally two approaches to specifying the meteorological forcing for temperature simulations in 19 a coastal ocean model. The first approach is based on observed data at meteorological stations to 20 obtain data on wind and other parameters to calculate the net heat flux. However, not all the 21 meteorological parameters (such as solar radiation, humidity, air temperature, dew point 22 temperature, cloud cover, etc.) are consistently measured at meteorological stations.

23 Furthermore, there are often gaps in measured data. Therefore, it is problematic to reply only on 
1 observed data for meteorological forcing in coastal ocean models for long-term simulations. The

2 second approach to specifying meteorological forcing is to use advanced meteorological forecast

3 model outputs that are available continuously over long time periods, such as MM5, NAM-WRF,

4 and NARR. In this study, NARR data are used for meteorological forcing in the FVCOM model

5 for temperature simulations.

6

7 NARR data are generated by the NOAA NCEP based on the regional meteorological model at a $8 \quad 32-\mathrm{km}$ resolution. For simplicity, we selected NARR output at one single grid point close to the 9 center of the model domain and applied the forcing uniformly to the entire model domain. The 10 selected NARR data location is near Seattle, WA (see Figure 1). NARR data sets provide all the 11 meteorological parameters required to calculate the net heat flux as model input in FVCOM. The 12 total net heat flux $\mathrm{H}_{\mathrm{NET}}$ is calculated based on the following formula:

$$
H_{N E T}=H_{S W}+H_{L W}-H_{S H}-H_{L H}
$$
where $H_{S W}$ is the net shortwave solar radiation; $H_{L W}$ is the net longwave solar radiation

15 (including the longwave back radiation); $H_{S H}$ is the sensible heat flux, and $H_{L H}$ is the latent heat

16 flux. Figure 2 shows the distributions of net shortwave and longwave solar radiation, the sensible

17 heat flux and latent heat flux for the year 2006. The net shortwave radiation, the sensible and

18 latent heat fluxes, shows strong seasonal variation with large values in the summer and low

19 values in the winter. It should be noted that the negative values in sensible heat flux from NARR

20 data represent heat transfer from the atmosphere to the water. The total net heat flux calculated

21 based on Eq. (7) is plotted in Figure 3. We can see that in general, the net heat flux is the highest

22 in the summer and the lowest in winter.

23 
1 The hydrodynamic model of Puget Sound was run with a 10-second time step for the entire year 2 of 2006 using the net heat flux calculated by Eq. (7) based on NARR outputs. All model input 3 files were interpolated linearly into the 10 -second intervals in the model during model 4 simulations. A 1-year model run with 64 computational cores requires about 34 hours in real 5 time. Due to the lack of long-term series temperature data, we compared model results to the 6 monthly datasets collected by the Washington Department of Ecology. Model results at surface 7 and bottom layers in the model were extracted for comparisons in three observation stations 8 along the mains stem of Puget Sound: Admiralty Inlet (ADM), Central Puget Sound (PSB), and 9 Nisqually at South Puget Sound (NSQ). Figure 4 shows the comparisons of surface and bottom 10 temperatures between model results and observed data for year 2006. Data for January, July, 11 November, and December were not available at Station ADM and PSB. The model was able to 12 capture the seasonal variations from cooling in the winter and warming in the summer. In 13 general, seasonal variations in temperature are small near the entrance of Puget Sound at 14 Admiralty Inlet and increase gradually towards the south end of Puget Sound. However, it is 15 noticed that the ranges of seasonal variations were under-predicted at all stations.

18 The results of water-temperature predictions with direct use of the original NARR outputs 19 indicated that NARR meteorological forcing may under-estimate the net flux in Puget Sound for 20 the period of 2006 . This may be due to the relatively coarse resolution of the NARR outputs $21(32 \mathrm{~km})$, and net heat flux calculated based on NARR outputs do not take into account the 22 dynamic feedback of the water-surface temperature simulated in the hydrodynamic model. To 23 evaluate this, we compared the NARR heat flux to the estimated net heat flux using real 
1 observed data based on heat-exchange equations. The formulas used for the heat-exchange 2 calculation between water and atmosphere are similar to those in the CE-QUAL-W2 model 3 (Cole and Wells, 2009). In general, the net heat flux can be calculated based on the following 4 formula:

5

6

$$
\phi_{n}=\phi_{s n}+\left(\phi_{a n}-\phi_{b r}\right)-\phi_{e}-\phi_{c}
$$

The first term $\phi_{s n}$ in Eq. (8) is the net shortwave solar radiation defined as (Wunderlich, 1972):

$$
\phi_{s n}=\left(2.044 \times A_{0}+0.1296 \times A_{0}{ }^{2}-1.941 \times 10^{-3} \times A_{0}{ }^{3}+7.591 \times 10^{-6} \times A_{0}{ }^{4}\right) \times
$$

where $C$ is the cloud cover ratio; $A_{0}$ is the solar altitude as a function of time and latitude; $B_{0}$ is the unit conversion factor. The second term $\phi_{a n}$ in Eq. (8) is the incoming longwave radiation minus the reflected longwave radiation:

$$
\phi_{a n}=0.97 \times 5.31 \times 10^{-13} \times\left(T_{a}+273.15\right)^{6} \times\left(1+k C^{2}\right)
$$

where $T_{a}$ is air temperature at $2 \mathrm{~m}$ height above water surface, and $k$ is a constant. The third $\phi_{b r}$ term in Eq. (8) is the longwave back radiation:

$$
\phi_{b r}=5.51 \times 10^{-8} \times\left(T_{s}+273.15\right)^{4}
$$

where $T_{s}$ is the water surface temperature. It should be noted that $\left(\phi_{a n}-\phi_{b r}\right)$ is equivalent to the total net longwave radiation flux defined in NARR output. The fourth term, $\phi_{e}$, in Eq. (8) is the latent (evaporation) heat flux:

$$
\phi_{e}=f\left(W_{z}\right)\left(e_{s}-e_{a}\right)
$$

where $f\left(W_{z}\right)$ is the empirical wind speed function for heat flux; $e_{s}$ is the saturated vapor pressure at water surface which is a function of dew point temperature; $e_{a}$ is the vapor pressure of air measured at a distance $2 \mathrm{~m}$ above the water surface and is a function water surface temperature. The last term, $\phi_{c}$, in Eq. (8) is the sensible (conductive) heat flux:

$$
\phi_{c}=b f\left(W_{z}\right)\left(T_{s}-T_{a}\right)
$$


1 where $\mathrm{b}$ is the Bowen Constant, and $T_{s}$ is the water-surface temperature.

2 Observed meteorological data at NOAA real-time stations were used to calculate the net heat 3 flux [see Eq. (8) and Eq. (9) to Eq. (13)]. Measured air temperature, dew point temperature, 4 water-surface temperature, and wind speed data at NOAA meteorological stations at Seattle and 5 Tacoma were obtained. No cloud cover data were available at the NOAA meteorological 6 stations, and therefore no cloud cover was assumed in the calculation. This implies that the net 7 heat flux calculation would be over-estimated, especially in the Pacific Northwest region. Some 8 missing data gaps in the datasets were filled with other observed data in the nearby 9 meteorological stations or interpolated. A comparison of measured and NARR air temperatures

10 is shown in Figure 5. It is seen that the NARR forecast air temperatures are in agreement with 11 the NOAA observed temperatures in daily, weekly, and seasonal variations. Comparison of wind 12 sticks between NOAA observed data and NARR outputs are shown in Figure 6. It is seen that the 13 NARR wind speed output is generally in agreement with the observed data.

14 The calculated net heat flux based on NOAA observed data is compared to NARR outputs for 15 the period of August 2006 (Figure 7). We can see a good correlation between the NOAA data 16 and NARR data in daily variations with warming during the mid-day (positive heat flux) and 17 cooling during the night (negative heat flux). However, it is also noticeable that the NARR 18 outputs are smaller than the calculated net heat flux based on observed data. To further evaluate 19 the range of seasonal variations for NARR net heat flux, we calculated the daily maximum and 20 minimum distributions of net heat fluxes from NARR outputs and NOAA observations. Figure 7 21 shows that the NARR heat flux is lower than that calculated based on NOAA-observed data from 22 late spring to the end of summer. It should be noted that the net heat flux-based NOAA-observed 23 data are expected to be over-predicted because cloud cover was neglected in the calculation, 
1 which is an important factor to consider in the Pacific Northwest coast. It is also noted the

2 estimated net heat flux becomes lower than the NARR output after October, which may explain

3 the over-prediction of water temperatures in the later part of the year in Station NSQ (Figure 4).

4

$5 \quad 3.3 \quad$ Simulations with Improved NARR Forcing

6 Based on the comparisons of NARR and observed net heat flux distributions, we increased

7 NARR heat flux by $15 \%$ after trial and error sensitivity tests were conducted. We also replaced

8 the NARR net heat flux values with observed data in October, November, and December. The

9 model then was re-run with the modified meteorological forcing. Figure 9 shows new model

10 results for predicted surface and bottom water temperatures at Stations ADM, PSB, and NSQ.

11 Compared to Figure 4, the level of agreement between model results and observed data was

12 much improved. The model was able to reproduce the seasonal variations in temperature from

13 fully mixing in early spring (February to April), development of stratification in the summer and

14 early fall (June to October), and final turnover in the winter (November and December) where

15 surface temperatures were colder than bottom temperatures. Furthermore, the model also

16 successfully predicted the spatial variations of stratification observed in the data. For example,

17 temperature stratification at the entrance of Puget Sound (Station ADM in Admiralty Inlet) is

18 greater than that at the central Puget Sound (Station PSB). Towards the south end of Puget

19 Sound (Station NSQ), stratification increased again, and seasonal variations became more

20 evident. Model results also showed that temperatures (especially bottom temperatures) increase

21 from the entrance of Puget Sound to the South Puget Sound, consistent with observed data.

22 


\section{Summary}

2 In this paper, an approach that uses advanced meteorological forecast model outputs to drive a 3 coastal ocean model for hydrodynamic simulation, including water temperature, was 4 investigated. The simulation of water temperature as part of the hydrodynamics in estuarine and 5 coastal modeling is still not done as routinely as is salinity in actual practice. This is partially 6 because of the assumption that density-induced baroclinic motion is more dominated by the 7 salinity gradient than the temperature gradient. Another important factor that limits the 8 application of water-temperature simulation in estuarine and coastal hydrodynamic modeling is 9 the lack of complete meteorological forcing data, such as wind, solar radiation, and heat fluxes.

10 In large estuarine systems such as Puget Sound and the northwest straits, the effect of 11 temperature on baroclinic circulation could become as significant as salinity when surface heat

12 changes play an important role in temperature variations. The availability of advanced 13 meteorological model outputs has made it possible and practical to conduct long-term 14 simulations of water temperature in coastal modeling. The North American Region Re-analysis 15 (NARR) outputs produced by NOAA on a continuous basis were linked to the Puget Sound 16 hydrodynamic model constructed based on FVCOM in this study to simulate a year-long (2006) 17 water-temperature distribution in Puget Sound. Comparisons of NARR outputs and observed 18 data indicated that some parameters of NARR outputs, such as air temperatures, are quite 19 consistent with the observed data while heat fluxes taken directly from NARR tend to be lower 20 than required for matching observed temperature data for the study period in Puget Sound.

21 Although uncertainties exist in NARR outputs and the outputs are in 3-hour intervals, the 22 hydrodynamic model driven with NARR data showed good agreement of predicted water 23 temperatures with observed data over a full-year cycle in Puget Sound. Additional modeling 
1 analysis also indicated that meteorological model outputs, such as from NARR, can be improved 2 with some guidance from real observation if available to improve the accuracy of model 3 predictions of water temperatures. While this study provides a useful approach to modeling 4 estuarine circulation and water temperature using the meteorological model outputs combined 5 with real observation, more work is needed to further improve the accuracy of the model 6 prediction for coastal water temperatures. For example, heat flux outputs from meteorological 7 models are not directly coupled to the water temperatures in the coastal ocean models in 8 temperature simulations. A potential improvement is the inclusion of feedback of water 9 temperature in the heat-exchange calculations in the coastal ocean model with meteorological 10 parameters instead of heat fluxes from meteorological model outputs. Other potential improvements include using satellite sea surface temperature images to provide more data for model validations and to implement spatial varying meteorological forcing using higher 13 resolution meteorological model outputs such as NAM-WRF (in 12-km resolution). 
Black T. (1994) "The new NMC mesoscale eta model: description and forecast examples." Weather Forecasting, vol 9, pp 265-278.

5 Capet X.J., Marchesiello P. and McWilliams J.C. (2004) "Upwelling response to coastal wind profiles." Geophys. Res. Lett. vol 31, no. 13, L13311/1-L13311/4.

7 Charles M.E. and Colle B.A. (2009) "Verification of Extratropical Cyclones within the NCEP Operational Models. Part I: Analysis Errors and Short-Term NAM and GFS Forecasts.”

9 Weather and Forecasting, vol 24, no. 5, pp 1173.

10 Chen C., Liu H., and Beardsley R.C. (2003) "An unstructured, finite-volume, three-dimensional, primitive equation ocean model: application to coastal ocean and estuaries." J. Atm. \& Oceanic Tech., vol 20, pp 159-186.

Chen C., Xue P., Ding P., Beardsley R.C., Xu Q., Mao X., Gao G., Qi J., Li C., Lin H., Cowles G., and Shi M. (2008) "Physical mechanisms for the offshore detachment of the Changjiang diluted water in the East China Sea." J. Geophy. Res., vol 113, C02002, doi:10.1029/2006JC003994.

17

$$
\text { doi.10.1029/2006JC003994. }
$$

Chen C, Beardsley R.C., Hu S., Xu Q., and Lin H. (2005) "Using MM5 to hindcast the ocean surface forcing fields over the Gulf of Maine and Georges Bank region." Journal of Atmospheric and Oceanic Technology, vol 22, no. 2, pp 131-145.

Chen C, Beardsley R.C. and Cowles G. (2006) "An unstructured grid, finite-volume coastal ocean model (FVCOM) system." Special Issue entitled "Advances in Computational Oceanography." Oceanography, vol 19, no. 1, pp 78-89. 
1 Cole T.M. and Wells S.A. (2009) "CE-QUAL-W2: A Two-Dimensional, Laterally Averaged, Hydrodynamic and Water Quality Model," Version 3.6 User Manual. Instruction Report EL-08-1, U.S. Army Corps of Engineers, Washington, DC 20314-1000.

Dudhia J. (1993) "A nonhydrostatic version of the Penn State/NCAR mesoscale model: Validation tests and simulations of an Atlantic cyclone and cold front." Mon. Wea. Rev., vol 121, pp 1493-1513.

Ebbesmeyer C.C., Coomes C.A., Cannon G.A., and Bretschneider D.E. (1989) "Linkage of ocean and fjord dynamics at decadal period," p. 399-417. In: D.H. Peterson [ed.], Aspects of climate variability in the Pacific and western Americas. Geophysical Monograph vol 55. American Geophysical Union.

Finlayson D.P., Haugerud R.A., Greenberg H., and Logsdon M.G. (2000) "Puget Sound Digital Elevation Model." University of Washington. Seattle, WA.

Flater D. (1996) “A Brief Introduction to XTide." Linux Journal, vol 32, pp 51-57.

Foreman M.G.G. (1978) "Manual for Tidal Currents Analysis and Prediction. Pacific Marine Science Report 78-6." Institute of Ocean Sciences, Patricia Bay, Sidney, B.C., (2004 revision).

Foreman M.G.G., Czajko P., Stucchi D.J., and Guo M. (2009) "A finite volume model simulation for the Broughton Archipelago, Canada. Ocean Modelling.” vol 30, no. 1, pp $29-47$. 
1 Frick W.E., Khangaonkar T., Sigleo A.C., and Yang Z. (2007) "Estuarine-ocean exchange in a North Pacific estuary: comparison of steady state and dynamic model." Estuarine, Coastal and Shelf Science, vol 74, no. 1-2, pp 1-11. doi:10.1016/j.ecss.2007.02.019

Gomez-Gesteira, M., Moreira C., Alvarez I., and deCastro M.E.. (2006) "Transport along the Galician coast (northwest Spain) calculated from forecasted winds.” J. Geophys. Res., vol. 111, no. C10, C10005 10.1029/2005JC003331.

Grell G.A., Dudhia J., Stauffer, D.R. (1995) "A description of the Fifth-Generation Penn State/NCAR Mesoscale Model (MM5).” NCAR Tech. Note. TN-398+STR, [URL: http://www.mmm.ucar.edu/mm5/doc1.html]

Holbrook J. R., and Halpern D. (1982) "Winter-time near surface currents in the Strait of Juan de Fuca," Atmos. Ocean, vol 20, pp 327-339.

Huang H., Chen C., Blanton J.O., and Andreade F.A. (2008) "Numerical study of tidal asymmetry in the Okatee Creek, South Carolina," Estuaries, Coastal and Shelf Science, vol 78, pp 190-202.

Huang A, Rao Y.R., and Lu Y. (2010) "Evaluation of a 3-D hydrodynamic model and atmospheric forecast forcing using observations in Lake Ontario," J. Geophys. Res., vol 115, C02004, doi:10.1029/2009JC005601.

Isobe A., and Beardsley R.C. (2006) “An estimate of the cross-frontal transport at the shelf break of the East China Sea with the Finite Volume Coastal Ocean Model.” J. Geophys. Res. vol 111, C03012 
1 Koracin D., Dorman C.E., and Dever E.P. (2004) "Coastal perturbations of marine layer winds, wind stress, and wind stress curl along California and Baja California in June 1999." Journal of Physical Oceanography vol 34, pp 1152-1173.

Lin Y., Mitchell K.E., Rogers E., Baldwin M.E., and DiMego G.J. (1999) “Test assimilations of the real-time, multi-sensor hourly precipitation analysis into the NCEP Eta model." Preprints, 8th Conf. on Mesoscale Meteorology, Boulder, CO, Amer. Meteor. Soc., pp 341-344.

Lopes J.F., Cardoso A.C., Moita M.T., Rocha A.C., and Ferreira J.A. (2009) "Modelling the temperature and the phytoplankton distributions at the Aveiro near coastal zone," Portugal Ecological Modelling, vol 220, no 7, pp 940-961.

Mark D.J.., Spargo E.A., Westerink J.J., Luettich R.A. (2004) "ENPAC 2003: a tidal constituent database for Eastern North Pacific Ocean.” Tech. Rep. ERDC/CHL TR-04-12, U.S. Army Corps of Engineers.

Mesinger F., DiMego G., Kalnay E., Shafran P., Ebisuzaki W., Fan W., Grumbine R., Higgins W., Lin Y., Mitchell K., Parrish D., Rogers E., Shi W., Stokes D., and Woolen J. (2003) Mesinger F., DiMego G., Kalnay E., Mitchell K., Shafran P., Ebisuzaki W., Jovic D., Woollen J., Roger E., Herbery E., Ek M., Fan Y., Grumbline R., Higgins W., Li H., Lin Y., Manikin G., Parrish D., and Shi W. (2006) "North American regional reanalysis," Bulletin of the American Meteorological Society, vol 87, pp. 343-360. 
1 Michalakes J., Dudhia J., Gill D., Henderson T., Klemp J., Skamarock W., and Wang W. (2004). "The Weather Research and Forecasting Model: software architecture and performance." In: 11th ECMWF Workshop on the use of High Performance Computing in Meteorology, edited by George Mozdzynski. Reading, U.K.

Moore S.K., Mantua N.J., Kellogg J.P., and Newton J.A. (2008) "Local and large-scale climate forcing of Puget Sound oceanographic properties on seasonal to interdecadal timescales." Limnol. Oceanogr., vol 53, no. 5, pp 1746-1758.

Newton J.A. (1995) "Observations of El Niño weather conditions reflected in the temperatures and salinities of monitoring stations in Puget Sound," p. 979-991. In: Proceedings of the 1995 Puget Sound Research Conference. 1. Puget Sound Action Team.

Otero P., and Ruiz-Villarreal M. (2008) "Wind forcing of the coastal circulation off north and northwest Iberia: Comparison of atmospheric models," J. Geophys. Res., vol 113, C10019, doi: 10.1029/2008JC004740.

Rogers E., Black T.L., Deaven D.G., DiMego G.J., Zhao Q., Baldwin M., Junker N.W., and Lin Y. (1996) "Changes to the operational "early" Eta Analysis/Forecast System at the national centers for environmental prediction." Weather Forecasting, vol 11, pp 391-413.

Qi J., Chen C., Beardsley R.C., Perrie W., Cowles G.W., and Lai Z. (2009) "An unstructuredgrid finite-volume surface wave model (FVCOM-SWAVE): Implementation, validations and applications." Ocean Modelling, vol 28, no. 1-3, pp 153-166.

Shore J.A. (2009) "Modelling the circulation and exchange of Kingston Basin and Lake Ontario with FVCOM. Ocean Modelling," vol 30, no. 2-3, pp 106-114. 
1 Signell R.P., Carniel S., Cavaleri L., Chiggiato J., Doyle J.D., and Sclavo M. (2004)

"Assessment of wind quality for oceanographic modelling in semi-enclosed basins," J. Mar.

3 Syst., vol 53, pp 217-233, doi:10.1016/jjmarsys.2004.03.006.

4

5 Tinis S., Thomson R.E., Mass C., and Hickey B. (2006) "Comparison of MM5 and meteorological buoy winds for the west coast of North America," Atmos. Ocean, vol 44, pp 65-81.

8 Thomson R.E., Mihaly S.F., and Kulikov E.A. (2007) "Estuarine versus transient flow regimes in Juan de Fuca Strait.” J. Geophys. Res. vol 112, C09022, doi:10.1029/2006JC003925.

Weisberg R.H., and Zheng L. (2006) "Circulation of Tampa Bay driven by buoyancy, tides, and winds, as simulated using a finite volume coastal ocean model." J. Geophys. Res. vol 111, C01005, doi:10.1029/2005JC003067

Wunderlich W.O. (1972) "Heat and mass transfer between a water surface and the atmosphere." Lab. Report No. 14, Tennessee Valley Authority Engineering Laboratories, Norris, TN.

Yang Z. and Khangaonkar T. (2008) "Modeling of Salt Intrusion, Intertidal Mixing, and Circulation in a Braided Estuary." J. Coastal Research, vol 52, pp 171-180. River Estuary Using an Unstructured Grid Ocean Model." Ocean Modelling, vol 28, pp 34-49, doi: 10.1016/j.ocemod.2008.07.004. "Hydrodynamic and Ecological Assessment of Nearshore Restoration: A Modeling 
B.23 


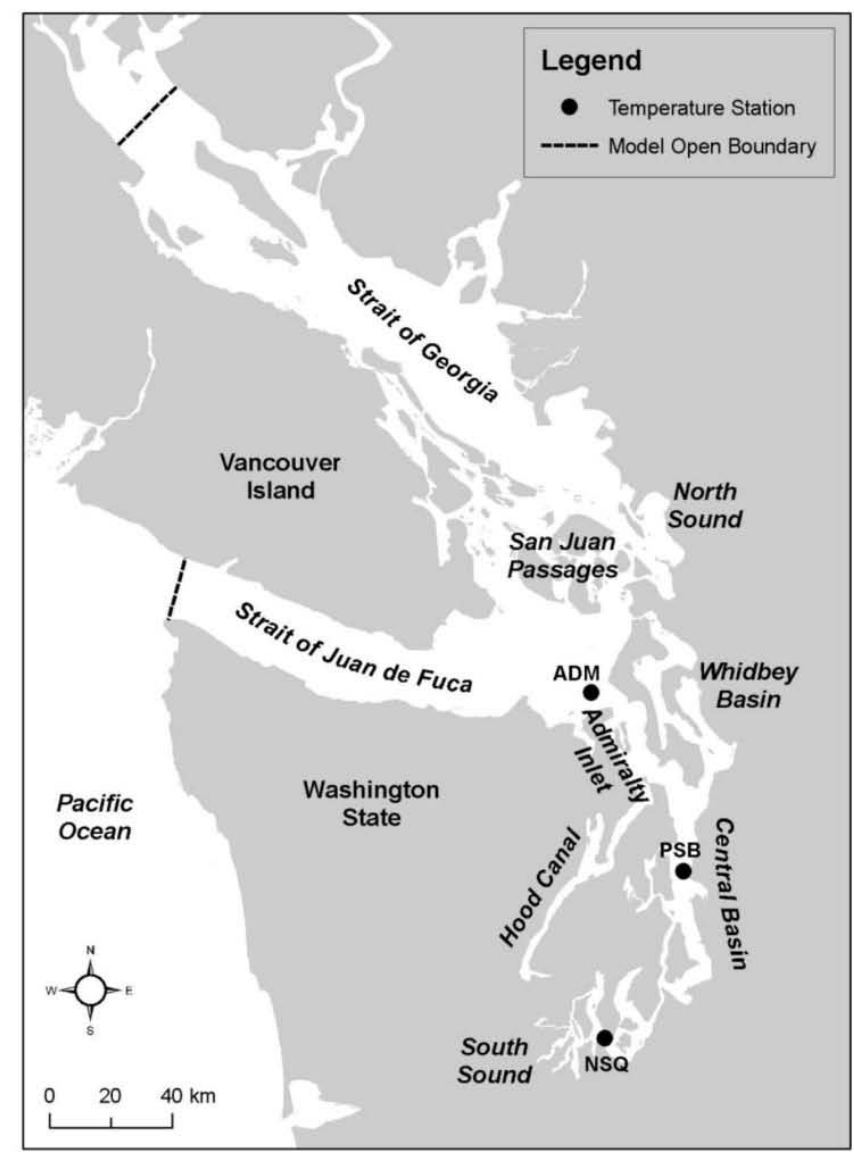

Figure 1. Study Domain - Puget Sound (update with new station - ADM, PSB, NSQ) 

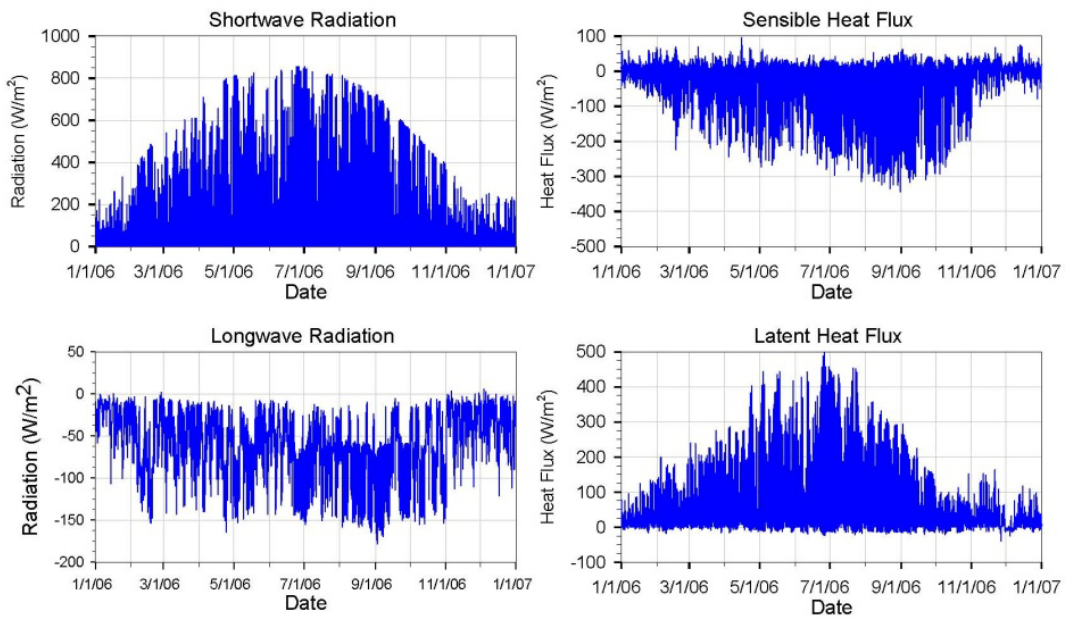

Figure 2. NARR Predicted Heat Fluxes Near Seattle, WA

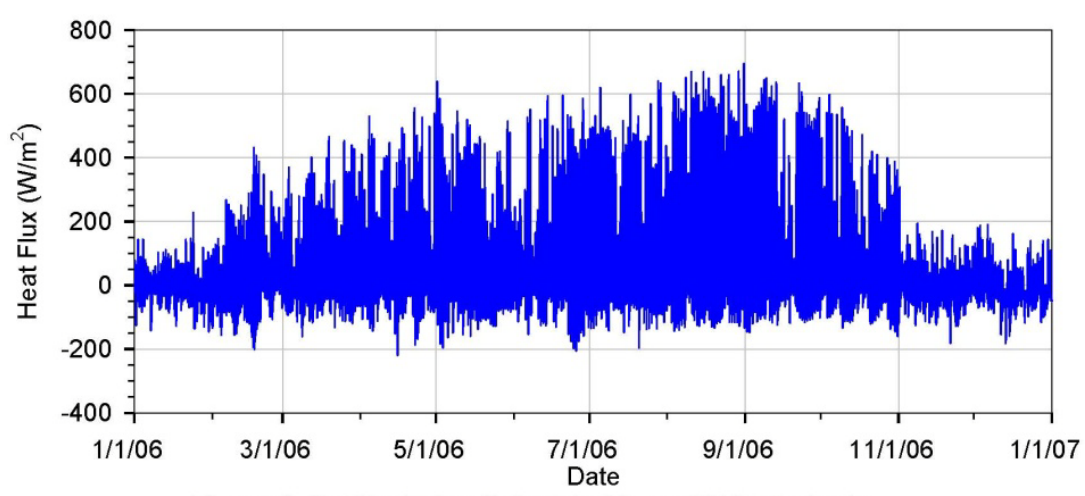

Figure 3. Net Heat Flux Calculated from NARR Outputs 

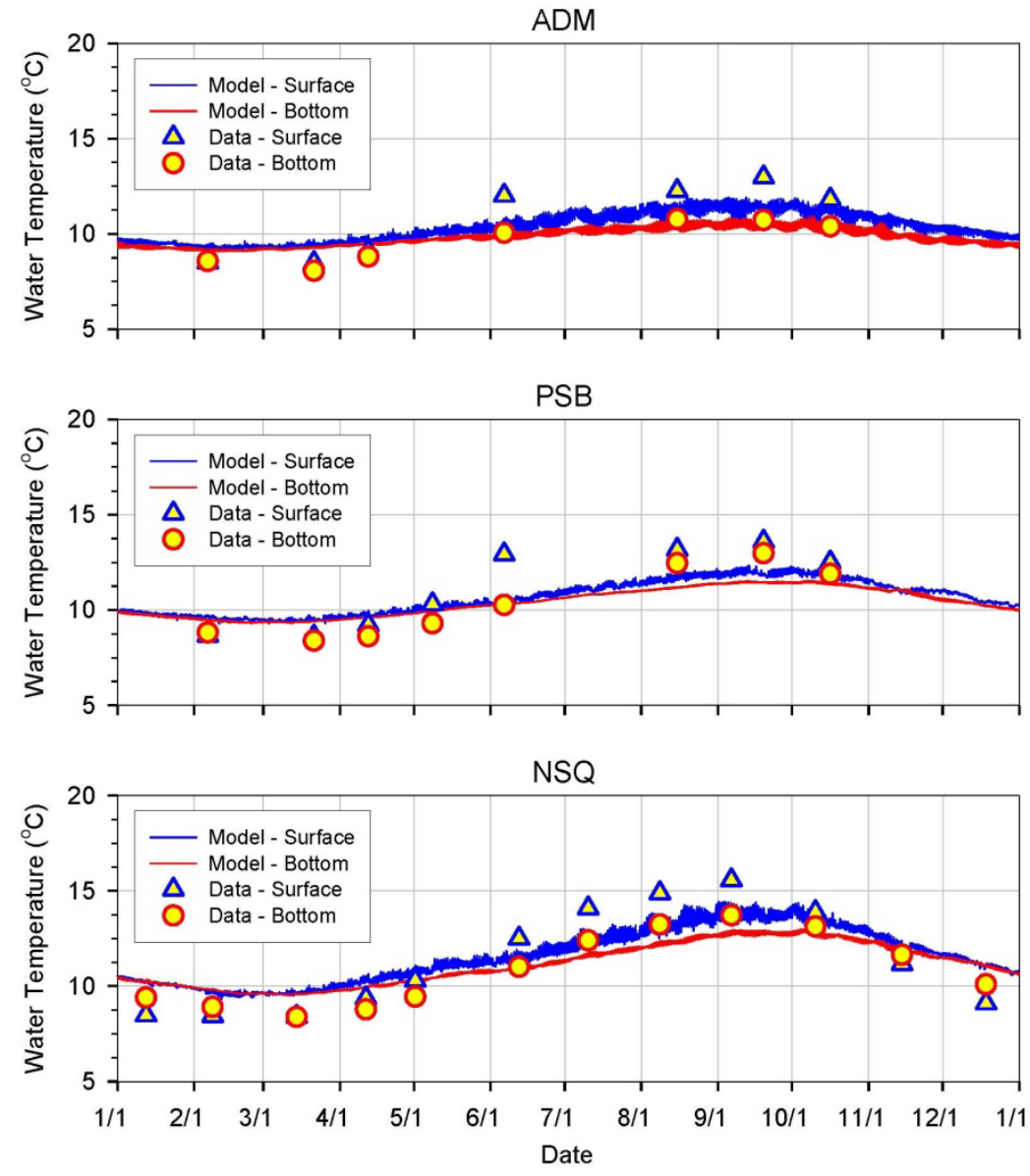

Figure 4. Comparisons of Modeled and Observed Temperatures at three locations in Puget Sound with NARR Forcing 


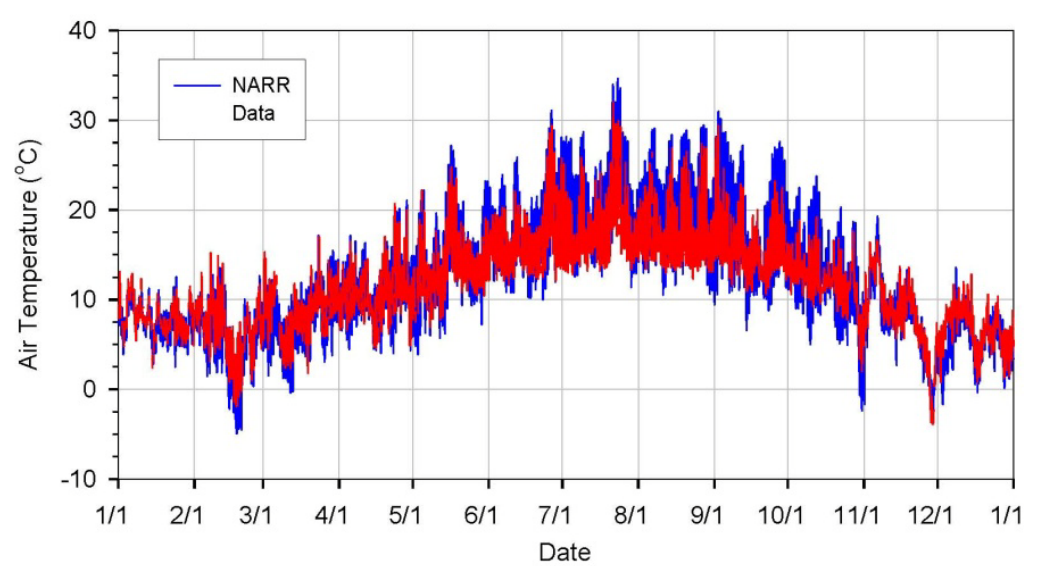

Figure 5. Comparison of NOAA Observed and NARR Air Temperatures at Seattle, WA
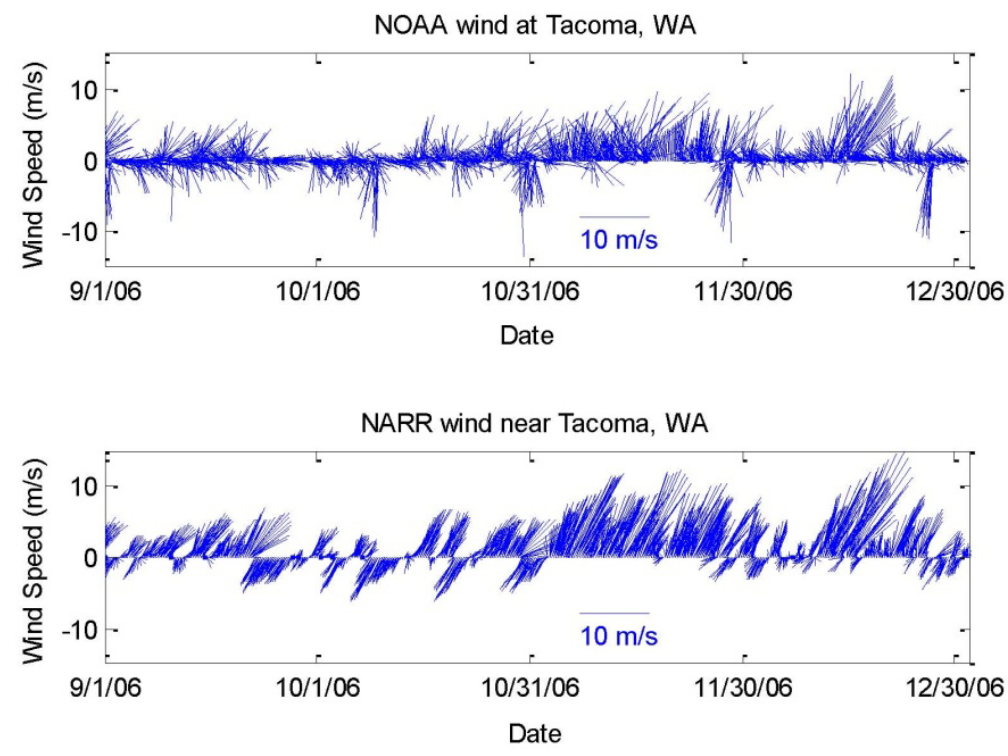

Figure 6. Comparison of NOAA Observed Wind Data and NARR Wind Output 


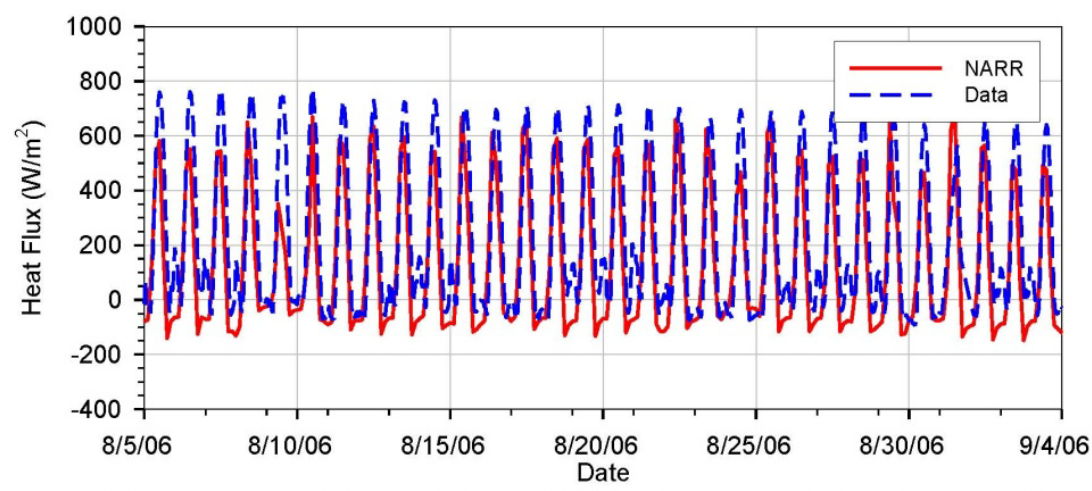

Figure 7. Comparisons of Net Heat Fluxes Calculated from NARR Outputs and Field Observed Data in Seattle Station

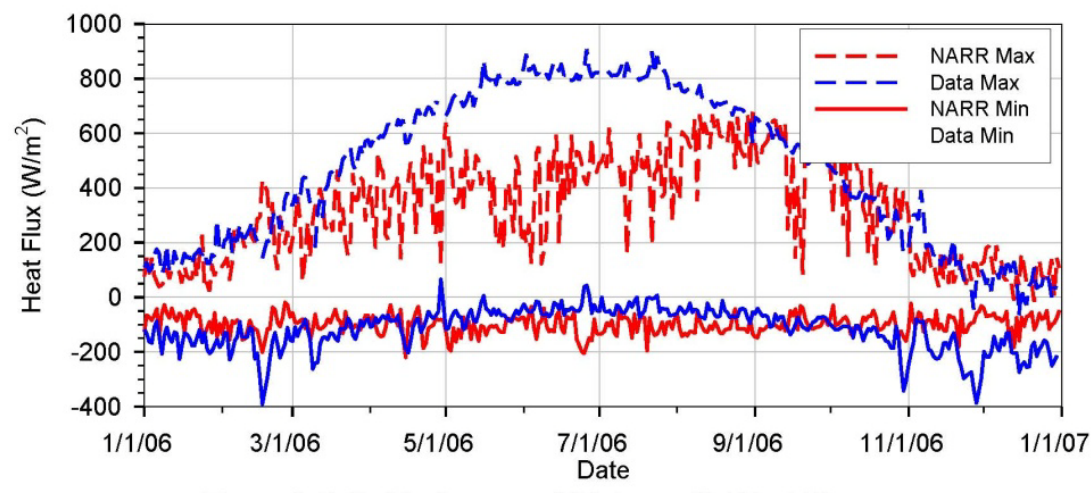

Figure 8. Daily Maximum and Minimum Net Heat Flux 

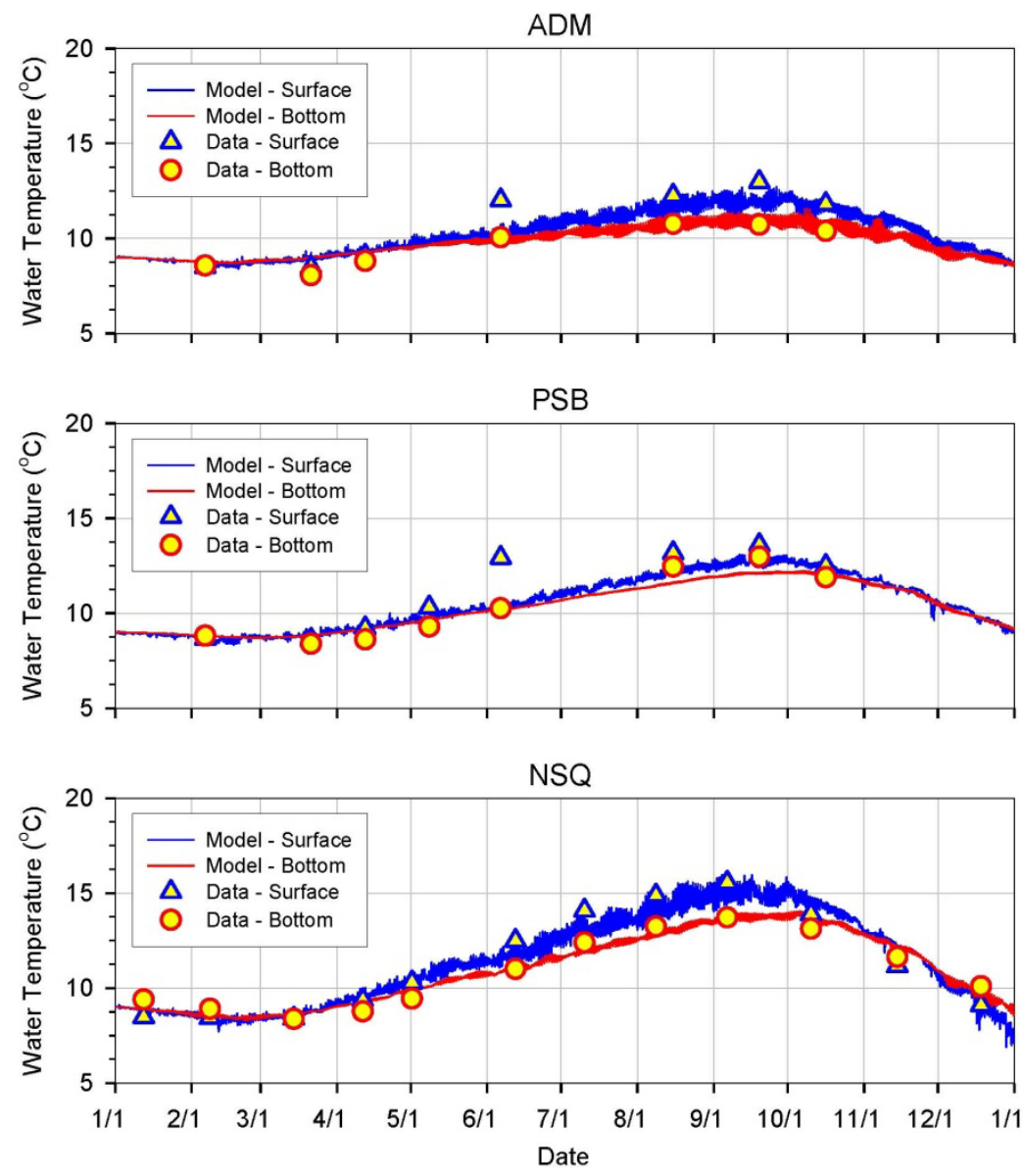

Figure 9. Comparisons of Modeled and Observed Surface and Bottom Water Temperatures in Puget Sound with NARR and Observed 



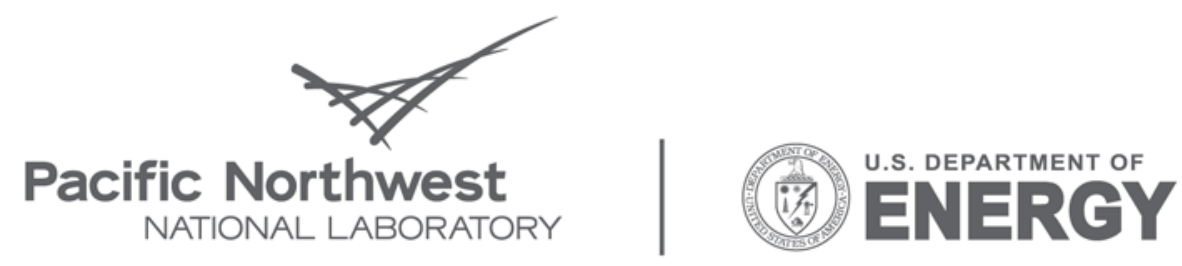

Proudly Operated by Battelle Since 1965

902 Battelle Boulevard

P.O. Box 999

Richland, WA 99352

1-888-375-PNNL (7665)

www.pnl.gov 